\title{
Tarım Kredi Kooperatifleri Faizsiz Kredi Sistemi Projesi ve Alternatif Bir Model Önerisi*
}

\author{
Agricultural Credit Cooperatives Interest-Free Credit System Project and An Alternative Model \\ Proposal
}

\author{
Maşuk Cahit UYSAL \\ Dr., Başmüfettiş (CICP), \\ Türkiye Tarım Kredi Kooperatifleri Merkez Birliği, \\ muysal@tarimkredi.org.tr \\ https://orcid.org/0000-0001-8196-0764
}

Makale Başvuru Tarihi: 27.06.2020

Makale Kabul Tarihi: 06.09.2020

Makale Türü: Araştırma Makalesi

\begin{abstract}
Anahtar
Kelimeler:

Kooperatifçilik

Hareketi,

Finansman,

Faizsiz Bankacılık, geçirmeyi gündemine alan TKK'da bu sistemin uygulanabilirliğinin tespitidir. TKK, finansman-kredi sorununu çözmesi durumunda, elindeki ortak ve şube ă̆l ile Türkiye'nin önemli ekonomik potansiyele haiz olan bir kurumu hâline gelecektir. Araştırmanın çalışma grubu amaçlı örnekleme yöntemlerinden "maksimum çeşitlilik örnekleme" tekniği kullanılarak belirlenmiştir. Çalışmada genel amaç çerçevesinde, konuyla ilgili temsil özelliği bulunan Co-opbank Pertama Malezya'da görüşme yapılmış ve gözlem gerçekleştirilmiştir. Aynı zamanda Türkiye'de bulunan TKK ve katılım bankaları incelenerek idarecileri ile görüşme yapılmıştır. Veri toplama yöntemi olarak gözlem ve yarı yapılandırılmış görüşme tekniği kullanılmıştır. Yapılan görüşmeler, veri doyumuna ulaşıldığına karar verildiğinden, araştırma açısından yeterli olarak değerlendirilmiştir. Elde edilen görüşme, gözlem ve doküman verileri içerik analizi yaklaşımıyla yorumlanmıştır. Araştırma neticesinde TKK'nın, kredi uygulamalarının faizsiz kredilendirme sistemine benzer olduğu, özkaynaklar dışından sağlanan finansman kaynaklarının ortak sermayelerinden gerçekleștirilmesi gerektiği ve tasarruf-kredi kooperatifi şeklinde örgütlenmesinin daha yerinde olacă̆ gözlenmiştir.
\end{abstract}

Keywords:

Cooperative

Movement,

Finance,

Interest-Free

Banking,

\section{ÖZET}

Türkiye Tarım Kredi Kooperatifleri (TKK), Türkiye tarım sektörünün önde gelen kuruluşlarından biridir. Bu çalışmanın amacı, günümüzde yaşanan ekonomik sorunlarla birlikte faizsiz kredilendirme sistemini hayata

\begin{abstract}
Turkish Agricultural Credit Cooperatives (TACC) is one of the leading institutions of Turkey's agricultural sector. In this context, the purpose of this study is to determine the applicability of the interest-free credit system in TACC, which has in its agenda putting this system into practice due to today's economic problems. In case the financing-credit problem is solved, TACC, with its stakeholder and branch network, will become an institution with significant economic potential in the country. The study group was determined by using "maximum diversity sampling" technique. In the application part, Co-opbank Pertama Malaysia has been interviewed and observed as a representational organization. At the same time, TACC and Islamic banks in Turkey have been examined and interviews are held with their managers. As a method of data collection, observation and semi-structured interview techniques were used. Interviews were evaluated as sufficient in terms of research since it was decided that data satisfaction was reached.Interview, observation and document data obtained were interpreted with the content analysis approach. The research concludes that TACC' credit applications are similar to the interest-free credit system, financing sources that other than equity should be realized from the common capital, and that it is more viable for TACC to organize as savings-credit cooperatives.
\end{abstract}




\section{GIRISS}

Kooperatifler, bir grup insanın önceden belirlenmiş bir amaca ulaşmak için gönüllü olarak bir araya geldiği, bu kapsamda da ekonomik ve sosyal alanda birlikte faaliyette bulunduğu demokratik birlikteliklerdir. Osmanlı Devleti'nde Mithat Paşa ile birlikte 1860'lardan itibaren varlı̆̆ını sürdüren kooperatifler, Türkiye Cumhuriyeti devletine miras olarak aktarılan kurumsal yapılardandır. Ancak tarihsel gelişimi incelendiğinde, günümüze değil kooperatifçiliğin daha çok sayısal anlamda olduğu görülmektedir. Sayısal artışın yanı sıra niceliksel gelişmenin de gerçekleşmesi için birtakım çalışmalar gerçekleştirilmiştir. Ancak elde edilen gelişmenin henüz istenilen düzeylere ulaşamadığı görülmektedir.

Kooperatiflerin niceliksel gelişimi önündeki en önemli sorun mali yetersizliklerdir. Özkaynaklar açısından yetersizlikler yaşayan kooperatifler, kredilendirmelerine karşılık finansman ihtiyaçlarını yeteri kadar giderememektedirler. Türk iktisat tarihi incelendiğinde, ekonomik gelişmeye yönelik devlet destekli politikalar ile birlikte kooperatifçilik müessesesinin ithal edilerek oluşturulmaya çalışıldığı görülür. Ancak ithal edilen sistemin Türkiye şartları ile bire bir örtüşmediği ve ihtiyacı tam olarak karşılayamadığı görülmektedir.

Başta gelişmekte olan ülkelerde olmak üzere gelir düzeyi düşük olan kesimler, refah düzeylerini artırmak için küçük tasarruflarını bir araya getirerek askeri, eğitim, aile, tarım gibi birçok alanda kurdukları kooperatifler yoluyla ortaya çıkardıkları katma değeri paylaşarak kazanç sağlamaktadır. Türk kooperatifçiliği geleneğine bakıldığında ise kooperatiflerin ortaklardan topladıkları cüzi sermaye ile ortak dışı çalışanlar tarafindan faaliyetlerini yürüttükleri, meydana gelen ticari kâr ile devamlılıklarını sağlamaya çalıştıkları ve bu nedenlerle de ortaklarına kâr payı ödemeyen ticari işletmelere dönüştükleri görülmektedir. Türkiye'de kooperatiflerin yaşadığı finansman sorununun temelinde de bu durum yatmaktadır.

Dünya kooperatifçiliğinin gelişim süreci incelendiğinde, kooperatiflerin finansman sorunlarının çözümü için kooperatifler bankası, tasarruf-kredi kooperatifi ve kredi birliği gibi çeşitli adlarla kurulan kooperatif müesseselerinin olduğu görülür. Ekonomik krizlerden en az etkilenen banka kurumlarından birisi kooperatif bankalarıdır. Bu özelliklerinin de etkisiyle mevduat bankaları, kooperatif bankalarının ortakları olmaktadırlar. Türkiye'de genel anlamda sadece tarımsal alanda faaliyet gösteren kooperatiflere kredi sağlamaya yönelik kooperatifler bankası kurulması dönem dönem gündeme gelmiş ve çeşitli girişimlerde bulunulmuştur. Ancak bu çalışmalar sonuçsuz kalmıştır.

TKK, Türkiye'nin tarım sektöründeki öncü kurumlarından birisidir. Günümüzde özkaynak sağlamada yaşanan güçlükler neticesinde TKK finansman-kredi sorununu çözümlemek için başta faizsiz kredilendirme sistemi olmak üzere çeşitli konuları gündemine almıştır. Çalışmamızda kooperatifçilik ve faizsiz bankacılık sistemi konuları incelendikten sonra ortaklarından mevduat toplama yetkisi de bulunan TKK'nın finansman sorununun nasıl çözülebileceğine dair model önerisi sunulması amaçlanmıştır.

\section{KAVRAMSAL VE KURAMSAL AÇIDAN KOOPERATIFÇILİK VE FAİZSİZ BANKACILIK}

Faizsiz bankacılık ve kooperatifçilik birbirinden farklı kavramlardır. Bu kavramların tanımlanması, temel ilkelerinin ırtaya konulması ve birbiri ile olan ilişkisinin ele alınması araştırmanın daha iyi anlaşılmasına katkı sağlayacaktır. Bu kapsamda kooperatifçilik ve temel ilkeleri ile faizsiz bankacılık ve Türkiye'deki tarihsel gelişimi sırasıyla ele alınmıştır.

\subsection{Kooperatifçiliğin Tanımı ve İlkeleri}

1163 numaralı Kooperatifler Yasasının 1 inci maddesinde kooperatif; "Tüzel kişilik taşıyarak ortakların belli ekonomik çıkarları ile iş ve yaşamlarına yönelik gereksinimlerini karşılıklı yardım, dayanışma ve kefillik yoluyla oluşturup korumak için gerçek ile kamu tüzel kişileriyle özel idareler, belediyeler, köyler, topluluklar ile derneklerce oluşturulan değişir ortaklı ve değişik sermayeli kuruluşlar", olarak tanımlanmışır.

Uluslararası Kooperatifleri Birliği'ne göre, dünya genelindeki kooperatifler üç farklı tür olarak sınıflandırılabilir (Birchall ve Ketilson, 2009:11);

- Tüketici Kooperatifleri: Maliyet fiyatına en yakın fiyatta üyelerinin mal ve hizmetleri satın almasına olanak sağlayan kooperatiflerdir. Finansal kooperatifleri de kapsayar. 
- Üretici Kooperatifleri: Üyelerinin girdi maliyetlerini azaltıp daha iyi pazarlama firsatları sunarak yüksek kâr elde etmelerine imkân tanıyan kooperatiflerdir. Tarımsal kooperatifleri de içinde barındırır.

- İşçi Kooperatifleri: İşçi ya da çalışanların ortak olduğu kooperatifler olarak ta adlandırılırlar. Üyelerine istihdam olanakları ile bilgi ve becerilerini geliştirme firsatları sağlayan kooperatiflerdir.

1844 yılında İngiltere'de Manchester şehrinin Rochdale kasabasında, 28 dokuma isçisi bir araya gelerek bir tüketim kooperatifi kurmuştur. Bu kooperatifin kurulması ile ortaya çıkan kooperatifçilik prensipleri, kooperatifçilik uygulamalarının dünya genelinde yaygınlaşması hususunda önemli katkılar sağlamıştır. Günümüzdeki uluslararası kooperatifçilik prensipleri, Rochdale Tüketim Kooperatifi'nde tatbik edilen usullerin geliştirilmiş hâlidir. Bu prensipler en son 23 Eylül 1995 tarihinde Uluslararası Kooperatifler Birliği Kongresinde 7 madde olarak kararlaştırılmıştır. Bu prensipler; gönüllü ile serbest giriş, ortakların demokratik yönetilmesi, ortakların ekonomik iştiraki, özerklik ile bağımsızlık, eğitim-öğretim ile bilgilendirme, kooperatifler arasında teşriki mesai ile sosyal sorumluluktur (Koç, 2001:3).

Çeşitli ülkeler evrensel kooperatifçilik ilkelerini, kendi yapı ve kooperatifçilik politikalarına göre anlamakta ve uygulamaları kendi yorum ve anlayışları üzerine dayandırmaktadır. Bugün çeşitli ekonomik düzenlere sahip ülkelerin hepsi kooperatifçilikte evrensel ilkelere bağlı kaldıklarını söylemekte ve hepsi de Uluslararası Kooperatifler Birliğinin çatısı altında toplanmaktadır.

\subsection{Faizsiz Bankacılık ve Gelişimi}

Ekonomi piyasalarında bulunan ve bankacılık alanında İslami bankacılık şeklinde bilinmekte olan faizsiz bankacılığın Türkiye'deki adı katılım bankacılığıdır. Katılım bankacılığı, mal ile hizmet devinimlerinin nakdi faaliyetlerle birbirine sıkı sıkıya bağlı olduğu, nakdi işlemlerin mal ya da hizmete karşllık olduğu ancak sağlanan kazancın kâr-zarar olarak paylaşıldığı bir sistem şeklinde ifade edilebilmektedir (Özsoy, 2013:10-11).

Günümüzde katılım bankacılığı; gelişmiş ülkelerin mali araç yelpazesini, ticari banka işlemlerine alternatif kurum olmak ile bunları İslami prensipler doğrultusunda yürütmeyi amaçlamaktadır (Özulucan ve Deran, 2009:89). İlk olarak 1984 yılında başlayan katılım bankacılığı sürecinde Albaraka Türk Katılım Bankası A.Ş., Kuveyt Türk Katılım Bankası A.Ş., Türkiye Finans Katılım Bankası A.Ş., Ziraat Katılım Bankası A.Ş., Vakıf Katılım Bankası A.Ş. ve Türkiye Emlak Katılım Bankası A.Ş. faaliyetlerini sürdürmektedir.

Katılım bankacılığında para sahiplerine Rab Al Maal, işleticilere Mudarib denilmektedir. Mudarib, önceden belirlenen kurallar çerçevesinde gelirini sağlamaktadır. Zarar durumunda, para sahipleri etkilenmektedir. Mudaribler, sarf ettikleri gayretin karşılığını kaybetmiş olmaktadır. Mudaribin özensizliğinden kaynaklanan ya da tarafların anlaşma hususlarına uymamalarından meydana gelen zararlar mudaribin üzerindedir (Zaim, 2005:119).

Türkiye'de Turgut Özal'ın başbakanlığı döneminde, ekonomik-finansal araçları çeşitlendirme ve geliştirme faaliyetleri kapsamına dünyadaki gelişmelere paralel olarak, 83/7506 sayılı Bakanlar Kurulu Kararı ile katılım bankalarının faaliyetine onay verilmiştir. 25 Şubat 1984 tarihinde 18323 sayılı Resmi Gazetede yayınlanan tebliğ ile katılım bankaları ile ilgili aşağıda özetlenen değişiklikler yapılmıştır (Turhan ve Gökalp, 1993:110);

- Kuruluş: Özel finans kurumu asgari 5 tane kurucusu olmak üzere 100 ortaklı bir A.Ş. şeklinde kurulabileceği hükme bağlanarak, Bankalar Kanununu değiştiren 1983/7506 sayılı Kanun Hükmünde Kararname ile bankaların kuruluşuna ilişkin kabul edilen esaslara paralel hükümler getirilmiştir.

- Fon Temini: Özel finans kurumunun kabul edebileceği fonlar cari hesaplar ve katılma hesapları olmak üzere iki bölümden oluşur. Hesabın işletilmesinden doğan masraflar özel finans kurumuna aittir. Özel finans kurumunun bu hesapların işletilmesinden doğan kâr-zarar payı azami \% 20'dir. Bu marj için de değişiklik yetkisi Merkez Bankasınındır.

- Fon Kullanımı: Murabaha, Mudarebe ve finansal kiralama şeklinde tanımlanmıştır.

Bazen özel cari ve katılım hesapları aracılığı ile toplanan fonlar yeterli olmadığı veya fon kaynaklarının çeşitlenmesi amaçlandığı durumlarda katılım bankaları murabaha sendikasyonu kullanabilecekleri gibi, kendi projeleri için de sukuk yoluyla fon toplayabilmektedirler (Tunç, 2010:167).

Katılım Bankaları fon sahiplerinden topladıkları fonları ihtiyaç içerisinde bulunan gerçek ya da tüzel kişilere: murabaha (peşin alıp vadeli satmak), mudarebe (emek-sermaye ortaklığı), müşareke (inan sermaye ortaklığı), icara (finansal kiralama), selem (peşin para veresiye satış), sukuk (İslami senet), karz-1 hasen (karş11ıssız borç), 
istisna (fiyatı önceden belli satın alım işlemi), komodite (uluslararası mal alım ve satımı) ile musakat ve mugarase (bağ-bahçe ortaklığı) şeklinde farklı yöntemler altında kullandırmaktadırlar. Bununla birlikte katılım bankalarında fon kullandırma temel olarak murabaha ve sukuk yöntemleri ile yapılmaktadır.

Katılım bankacılığının doğuşu Arap ülkelerinde meydana geldiği düşünülürken, yasal olarak bu faizsiz sistemin ilk tohumlarını İngiltere'nin attığı anlaşılmıştır. İngiltere bu kurumların ana iskeletini oluşturan düzenlemeleri hayata geçirmiştir. Diğer ülkeler bu ilk uygulamayı model alarak fikir edinmişlerdir. 1971'de Misır da kurulan Nasır Sosyal Bankası ve 1975 'te kurulan Dubai İslam Bankası, sanayi ve tarım gibi önemli alanları finanse eden gelişimin ilk örneklerini oluşturmuş̧tur (Akın, 1986:114).

İslam Kalkınma Bankası 1975 yılında Cidde'de kurulmuştur. Bankanın amacı, üye olan Müslüman ülkelerin ekonomik olarak kalkınması, ilerlemesi ve ortaklaşa hareket edilmesinin yanı sıra İslam Hukuku ilkelerine uyum gösterilmesini teşvik etmektir. Banka üye ülkelere projeler üreterek ekonomik ve sosyal olarak kalkınmasını hedeflerken, mali yardımlarda bulunarak kredi vermektir. Bankanın 2020 yılı itibariyle 57 ülkeden üyesi bulunmaktadır (ISDB, 2020).

Pakistan 1985 yılından sonra tamamıyla katılım bankacılığına yönelmiştir. Pakistan, katılım bankacılığın devlet kanalıyla zorunlu tutulduğu ülkelerin başında gelir. Pakistan devleti, faizsiz devlet tahvillerinin yönetimi için Citigroup ve HSBC Bankaları ile anlaşmıştır. Pakistan hükümeti halkın faiz araçlarından ve hizmetlerinden uzak tutulması için bu alanda çalışmalar yapmıştır. Pakistan topraklarında 1983'te ilk olarak al-Rajhi Company, İslam Bankası olarak faaliyete başlamıştır. Hizmetlerinin kalitesi ve başarısı diğer ülkelere kadar uzanmıştır. Bu banka leasing alanında dünyada önde gelen finans kurumlarındandır (Uçar, 1992:50).

Arap ülkelerindeki zengin fonları ülkeye kazandırmak ve ülke içerisindeki faize bulaşmaktan çekinen Müslüman gurbetçilerin birikimlerini işletmek için mevcut bankalarında diğer fonlardan faizsiz fonları ayıran bir bankacılık hizmeti sunmaktadır. Almanya'nın önde gelen bankalarından Dresdner Bank ve Deutsche Bank faizsiz kazanç getiren yatırım araçları bulundurmaktadır. Moskova'da faaliyete başlayan Bedir Bank, devletin yasal yükümlülüklerine uyarak çalışmalarını sürdürmektedir. Topraklarında 20 milyondan fazla Müslüman barındıran Rusya, ekonomisinin gelişmesine ve alternatif bir bankacılık hizmeti sunulmasına katkıda bulunmuştur. Bankanın hizmet sunduğu kitle genellikle kurumsal kimliğe sahip firmalardır. Şubeleşme yoluna giderek hizmet ağını ulaşabildiği her yere götürmeyi hedeflemiştir. Bu yolda kendisine destek verecek içerisinde Rusya Bankalar Derneği, Moskova Bankalar Birliği ve İslam Kalkınma Bankası'nın da bulunduğu İslami Bankacılık Konseyi'ne üye olmuştur (Doğan, 2008:39).

Malezya'da faizsiz sistemle çalışan bankalar, diğer geleneksel bankalardan farklı bir model ve düzenlemelere tabi tutulmaktadır. Kanunlar ve denetlemeler, rezerv miktarı, ödeme sistemleri, likidite oranı, banka kredi kabulleri ve ikincil pazarlar göz önüne alınarak oluşturulmuştur. Malezya'da işlem yapan bu bankalar, tüm hukuksal gereklilikleri yerine getirmektedir. 1983'te İslam Bankacılık Kanunu çıkarılmıştır. Bu yasa ile ülkedeki katılım bankaları Malezya Merkez Bankası'nın denetimi altına girmiş̧tir. Katılım Bankaları aracılığı ile yatırım sertifikası ve menkul kıymetler gibi faizsiz yeni ürünlerin ihracı başlamıştır. Likit özelliği bulunan bu ürünler ile bankaların likit ihtiyaçlarının karşılanması sağlanmıştır. Malezya'daki ilk katılım bankası olan Bank İslam Malaysia Berhad 1992 yılına gelindiğinde Kuala Lumpur Borsası'nda işlem görmeye başlamıştır. 1994 yılında, varlığını devam ettirmek isteyen katılım bankaları için faizsiz bir Interbank olan Islamic Interbank Money Market kurulmuştur. Malezya'da dual mevduat bankacılık modeli uygulaması ile katılım bankalarının ürünlerini diğer faizli bankalar müşterilerine sunabilmektedir (Özgür, 2007:49).

\subsection{Tarım Kredi Kooperatifleri ve Faizsiz Krediler}

Kooperatifler, 1581 sayılı Kanunun 3. ve Ana sözleşmenin 5. maddeleri uyarınca ortakların kısa ve orta vadeli kredi ihtiyaçlarını karşılamaktadır:

- İşletme Kredileri; ortağın tarımsal faaliyetini yürütmesi için nakit dâhil gerekli girdilerin temini amacıyla kullandırılan azami 1 yıl vadeli kredilerdir.

- Yatırım Kredileri; tarımsal işletmenin canlı ve cansız demirbaş unsurlarını oluşturan her çeşit tarımsal araç-gereç, traktör, biçer-döver, tarımsal araç lastikleri, sergi ve örtü malzemesi, arı kovanı, su ürünleri ekipmanları, ipekböcekçiliği ve kümes hayvancıllğında kullanılan canlı ve cansız donatma malzemeleri ve irat hayvanlarının sağlanması yanında bitkisel üretime yönelik fidan ihtiyaçlarının karşılanması amacıyla açılan kredilerdir. Bu kapsamda kullandırılacak kredilere en çok 4 yıla kadar vade verilebilecektir. 
- Tüketim Kredileri; Ortakların, Tarımsal kredi kapsamına girmeyen ihtiyaçlarının karşılanması için ayni ve belge karşılığ

- Faizsiz Krediler; Ortakların ihtiyaçlarının, finansman maliyeti ilave edilmek suretiyle belirlenecek bedel üzerinden vade tarihine kadar faizsiz bir şekilde karşılanmasına yönelik ayni olarak kullandırılan işletme veya yatırım kredileridir.

Faizsiz kredi kullanmak isteyen ortakların finansman ihtiyaçlarının karşılanması amacıyla vadeli faizsiz kredi kapsamında kredi de kullandırılabilmektedir. Vadeli faizsiz kredi uygulaması işletme kredileri için yapılmaktadır. Yatıım kredisine konu girdiler ise 1 yıla kadar vadeli faizsiz olarak kullandırılabilmektedir. Bu çerçevede tüm tarımsal girdiler ve tüketim maddeleri faizsiz olarak kredilendirilebilmektedir. Yem, motorin, tohum, fide, kömür, ilaç ve gübre girdileri bu kapsamdadır. Burada malın mevcut KDV dâhil satış fiyatı yani kredilendirilecek tutar üzerine ayni işletme kredilerine uygulanan toplam finansman oranı kadar vade farkı uygulanır. Ayrıca vadeli faizsiz kredi kapsamında, kredilendirilecek malın maliyeti, elde edilen komisyon, firsat maliyeti ve rekabet şartları göz önüne alınarak azami 180 güne kadar vade farkı hesaplanmadan kredilendirme işlemi yapılabilmektedir.

Kredilendirilecek malların faturası, sistem tarafından malın mevcut KDV dâhil satış tutarı üzerinden düzenlenir ve kullandırılan krediler için kredi hayat sigortası yapılmaktadır. Kredi hayat sigortası senet borç tutarı yani malın KDV'li satış fiyatı ile vade farkı tutarının ilave edilmesiyle elde edilen tutar üzerinden yapılacaktır. Vade farkı olarak hesaplanan tutar ortakların kredi limitinden düşülmemektedir. Tarım Kredi Koopertiflerleri faizsiz kredilendirme projesi ile kredi uygulamalarını tamamen faizsizlik prensibine göre yapılandırmayı gündemine almıştır.

\subsection{Türkiye Tarım Kredi Kooperatifleri ile Finansal Sorunları}

TKK'nın kuruluşu 1863 yılına, Mithat Paşanın kurmuş olduğu Memleket Sandıklarına dayanır. 1924 yılında 498 numaralı İtibari Tarımsal Birlikler Yasası, 1929 yılında 1470 numaralı Tarımsal Kredi Kooperatifleri Yasasıyla gelişimini sürdürürken, 1935 yılında yayınlanan 2636 numaralı Tarım Kredi Kooperatifleri Yasasıyla günümüzdeki anlamıyla kuruluşu gerçekleşmiştir. 1972 yılında çıkarılan kanunda, TKK'nın dikey teşkilatlanmasına zemin hazırlamıştır. TKK, TCZB içerisinde faaliyetlerini yütürürken 17 Mayıs 1977 tarihinde merkez birliğinin oluşturulmasıyla bağımsız çiftçi kurumu olmuştur (Türkiye Tarım Kredi Kooperatifleri Merkez Birliği Genel Müdürlüğü, 2007:71). 1985 yılında yayımlanan 3223 numaralı Yasa ile TKK, Tarım ve Orman Bakanlığı'nın koordineli kurumu durumuna gelirken denetlenmesi yine aynı bakanlığa aittir.

1581 numaralı Tarım Kredi Kooperatifleri ve Birlikleri Yasası'na göre TKK, üreticilerin ekonomik çıkarlarını sağlamak ile işle geçimleriyle alakalı gereksinimlerini elde etmek için karşılıklı yardım prensibine dayanan ve tüzel kişiliği bulunan değişir ortaklı, değişir sermayeli kuruluşlardır (Türkiye Tarım Kredi Kooperatifleri Merkez Birliği Genel Müdürlüğü, 2007:73).

28.06.1995 tarihinde hayata geçen 553 numaralı Kanun Hükmünde Kararname ile Tarım Kredi Kooperatifleri Yasasının birtakım maddelerinde değişiklikler yapılmıştır. Yapılan düzenleme sonucu TKK bir ölçüde özerk yapıya kavuşmuştur (İnan, 2008:152). 12 Nisan 2005 tarihli Resmî Gazetede yayımlanarak hayata geçen 5330 numaralı Tarım Kredi Kooperatifleri ve Birlikleri Yasasında Değişiklik Yapılması Hakkındaki Kanun ile de kooperatifçilik alanında önemli adımlar atılmış ve bu kooperatifler bağımsız hâle getirilmiştir.

TKK'ya kooperatifler bankası gibi faaliyet gösteren bir kuruluş da diyebiliriz. 1581 sayılı kanunda TKK'ların amaç ve faaliyet alanları belirtilirken mevduat toplamak, bankacılık faaliyetleri ile sigorta acenteliği gibi ifadeler kullanıldığı hâlde bugüne kadar uygulamada bu faaliyetlerin gerçekleşmediği görülmüştür.

Merkez birliği anasözleşmesinin 3 üncü maddesi " $b$ " bendine göre merkez birliği, bölge birlikleri ve kooperatiflerin finansman kaynakları elde etme ile bunları geliştirme yönünde her çeşit tedbiri sağlamak ile kredi faaliyetlerini düzenle gerçekleştirmekle görevlidir (Türkiye Tarım Kredi Kooperatifleri Merkez Birliği Genel Müdürlüğ̈̈, 2006:119). Bu amaçla TKK'nın finansal ve mali yapısının, performans gelişimine etki eden faktörlerin tespit edilerek, finansal plan ve stratejilerinin geliştirilmesi ve karşılaşılan tehditlerin doğru bir şekilde belirlenmesi önemlidir. TKK'nın özkaynakları Tablo 1.'de görüldüğü üzere satış karları, fonlar ve yedek akçe gibi unsurlardan oluşmaktadır. 
Tablo 1. Özkaynak Dağılımı (‡)

\begin{tabular}{|c|c|c|c|c|c|c|}
\hline YILLAR & SERMAYE & $\begin{array}{c}\text { SERMAYE } \\
\text { DÜZELTMESI } \\
\text { FARKI } \\
\text { OLUMLU }\end{array}$ & YEDEK AKÇE & FONLAR & $\begin{array}{c}\text { BİRİKMíS } \\
\text { NET KÂR }\end{array}$ & TOPLAM \\
\hline $\mathbf{2 0 1 3}$ & $450.317 .119,00$ & $275.792 .163,00$ & $1.284 .397 .477,00$ & $2.060 .106 .589,00$ & $307.961 .757,00$ & $4.378 .575 .103,00$ \\
\hline $\mathbf{2 0 1 4}$ & $511.189 .423,00$ & $275.206 .767,00$ & $1.486 .783 .022,00$ & $2.352 .571 .847,00$ & $87.740 .563,00$ & $4.713 .491 .622,00$ \\
\hline $\mathbf{2 0 1 5}$ & $570.809 .269,00$ & $275.129 .457,00$ & $1.583 .159 .027,00$ & $2.661 .328 .966,00$ & $134.221 .259,00$ & $5.224 .647 .978,00$ \\
\hline $\mathbf{2 0 1 6}$ & $612.564 .280,00$ & $275.106 .745,00$ & $1.600 .094 .067,00$ & $2.808 .091 .493,00$ & $549.091 .822,00$ & $5.884 .948 .407,00$ \\
\hline $\mathbf{2 0 1 7}$ & $646.303 .956,00$ & $274.628 .624,00$ & $1.602 .895 .277,00$ & $2.958 .067 .235,00$ & $954.493 .203,00$ & $6.436 .388 .295,00$ \\
\hline
\end{tabular}

Kaynak: Türkiye Tarım Kredi Kooperatifleri Merkez Birliği, 2018:34.

TKK'nın faaliyetleri kredi, girdi, tüketim gereçleri, sigorta görevleri, pazarlama görevleri, imalat ve sair faaliyetlerden oluşmaktadır. Ancak kooperatiflerin faaliyetleri genişledikçe personel gereksinimi de artmaktadır. 2013 yılında 4947 olan çalışan sayısı 2017'ye kadar 242 kişi azalarak 4705'e düşmüştür, personel giderleri ise 2014 yılı hariç artarak 2017 yılında 596.545.789,94 £’ye yükselmiştir (Türkiye Tarım Kredi Kooperatifleri Merkez Birliği, 2018:18). Yıllar itibariyle personel giderlerinde oluşan önemli artış özkaynaklardan kullandırılacak kredi oranını olumsuz etkilemektedir. Ayrıca Hazine kaynaklı gelir kayıpları özkaynakların artırılmasında yetersiz kalmaktadır ve tahsili geciken alacaklar da özkaynakların erimesine neden olmaktadır.

Ortakların sermaye taahhütlerini vadesinde yerine getirmemeleri nedeniyle kooperatiflerin finansal yapisı zayıflamaktadır. 2017 yılsonu itibariyle kooperatiflerin 572, bölge birliklerinin 264 ve merkez birliğinin de 85 milyon € olmak üzere toplam 921 milyon € olan sermaye taahhüdünün yetersiz kaldığ görülmektedir (Türkiye Tarım Kredi Kooperatifleri Merkez Birliği, 2018:35). TKK’nın 2017 yılı itibariyle ortak baş1 4.460,55 £ özkaynağı bulunmaktadır ve bu tutar yetersizdir.

Kooperatifler öz kaynaklarının büyük bir kısmını ortaklarına kredi vermek için kullanmaktadır. Finansal ve mali ihtiyaçlarını büyük oranda özkaynakları ile karşılamaya çalışan TKK'nın özkaynaklarının mevcut ekonomik büyümeye karşılık yetersiz kaldığ 1 görülmektedir. Bu doğrultuda finansman kaynağı olarak başta TCZB olmak üzere harici kaynaklara başvurulmaktadır. TCZB ve özel bankalar ile özkaynaklardan tahsis edilen kredi tutarları Tablo 2.'de gösterilmiştir. Kredi tahsisatlarının yapısı 2013-2017 arasında oldukça değişiklik göstermiş̧ir. Toplam kullandırılan kredilerde bankalardan tahsis edilerek kullandırılan kredilerin pay1 2013 yılında \%35 iken 2017 yılında \%51'e yükselerek özkaynaklardan kullandırılan kredi tutarını geçmiştir.

Tablo 2. TCZB ve Diğer Bankalardan Kullandırılan Kredi (‡)

\begin{tabular}{|c|c|c|c|c|c|}
\hline & 2013 & 2014 & 2015 & 2016 & 2017 \\
\hline Kullandırlan Kredi & $5.220 .835 .823,00$ & $5.947 .587 .441,00$ & $6.405 .798 .867,00$ & $6.765 .228 .505,00$ & $7.619 .314 .092,00$ \\
\hline $\begin{array}{c}\text { Bankalardan } \\
\text { Kullandırlan Kredi }\end{array}$ & $1.809 .935 .633,00$ & $2.537 .648 .322,00$ & $2.784 .169 .891,00$ & $3.370 .363 .005,00$ & $3.887 .655 .328,00$ \\
\hline $\begin{array}{c}\text { Banka Kredileri / } \\
\text { Kullandırlan Kredi }\end{array}$ & 0,35 & 0,43 & 0,43 & 0,50 & 0,51 \\
\hline
\end{tabular}

Kaynak: Türkiye Tarım Kredi Kooperatifleri Merkez Birliği, 2018, verileri kullanılarak oluşturulmuştur.

\subsection{Tasaruf-Kredi Kooperatif̧̧iliği}

Kırsal alanda yaşayan ve bankacılık hizmetlerinden yoksun olan topluluklar, tasarruf ve kredi kooperatifleri sayesinde bu hizmetlere erişebilmektedirler. Küçük ölçekli ve mikro işletmelerin finansmanında kredi kooperatifleri, işletmelerin finansal olarak desteklenmesini teşvik etmektedir. Birleşmiş Milletler, kredi kooperatifleri tarafından yürütülen bu tür hizmetleri fakir insanlara sürdürülebilir bir şekilde ulaşma yöntemi olarak tanımlamaktadır (World Bank, 2008:115). 
1860'l1 yılların Almanya'sında yaşanan tarımsal buhran esnasında sosyal reformcu olan Friedrich Raiffeisen, çiftçilerin kendi üretim metotlarını geliştirmek ve ürettikleri ürünlere uygun pazar imkânı sağlamak amacıyla onlara kredi verilmesinin bu ailelerin asıl ihtiyaç duyduğu yardım şekli olduğu kanaatine varmıştır (Birchall ve Ketilson, 2009:6). Friedrich Raiffeisen, yeni bir kooperatif türü olarak tasarruf ve kredi kooperatiflerini tasarlamıştır. Raiffeisen tipi kooperatifler, tasarruf ve ikraza dayanan bir sisteme göre faaliyet gösterirler. Tasarruf kredi kooperatif̧̧iliğinin özelliklerini özet olarak_şu şekilde belirtebiliriz (Çıkın, 1996:21-22);

- Güvenilir kurum olması,

- Tasarruf ve mevduat hesapları olması,

- Yatırımda bulunmak için tasarrufu teşvik etmesi,

- Tasarrufları güvenli bir şekilde toplaması ve yatırması,

- Daha çok nakit tasarrufu sağlaması,

- İşçilerin güvenle ve düşük maliyetle para gönderebilmesi,

- Safe Safe (Kırsal kesimde düşük maliyetli günlük hizmet) adı verilen yöntemi barındırması,

- Düşük işlem maliyeti alması, tasarruf araçlarının olması, sağlık sigortası hizmeti sunması,

- Üyelerinden topladığı mevduat ile finansman sağlaması,

- Kredilerin kolay sağlanması,

- Gayrimenkul ipoteği karşıllğı tarımsal kredi vermesi,

- Kredi bankalarına göre düşük faiz artışı yapması,

- Mevduat ve kredi faiz oran farkının düşük olması,

- Araç ve işletme kredileri de vermesi,

- İyi tarım uygulamalarını, üretimin artmasını ve kadınların üretime katılmasını sağlaması,

- Kriz dönemlerinden etkilenmemesi.

Tasarruf ve kredi kooperatifleri, finansman gereksinimi için sermaye piyasalarına bağımlı olmayıp, ancak üye mevduatları yoluyla finanse edilmektedir. İstikrarlı bir şekilde kâr sağlamaları ve nispeten tasarruf ve mevduata daha iyi erişim imkânları sunmalarıyla bilinen finansal kooperatifler, bireysel bankacılıkta oldukça güçlüdürler. $\mathrm{Bu}$ kooperatifler, yatırımcılardan kolay para elde etmek amacıyla değişik mali piyasalara gitmeleri mümkün değildir. Bu nedenle de kârlarını koruma ve daha az risk alma eğilimindedirler (de Vries, 2009:4). Bu durum, daha fazla miktarda sermaye rezervi bulundurma kriterine sahip olma nedenlerinden birini oluşturmaktadır. Riskten kaçınmalarına yönelik bir başka önlem de, ekstra güvenlik hizmeti sağlayan ek mevduat garanti programlarıdır.

Tasarruf ve kredi kooperatiflerinin dünyanın her yerinde büyümelerini sürdürdükleri görülmektedir (Develtere, Pollet ve Wanyama, 2008:67). Finansal krizlerle ilgili raporlar; ekonomik kriz sirasinda, tasarruf ve kredi kooperatiflerinin, varlıklar ve mevduatlardaki artış; artan kredi hacmi; üyelik sayılarında artış; daha uygun koşullarda faiz oranı ve daha fazla istikrar dâhil olmak üzere hemen her türlü iş kollarında yükseliş yaşandığını göstermektedir. Kriz dönemlerinde finansal kooperatifler yatırımlarında oldukça az bir kayba uğramışlar ve yatırımcıların çok az bir kısmı da devlet yardımına ihtiyaç duymuşlardır.

\section{TARIM KREDİ KOOPERATIFLERİ FAIZZSIZ KREDİ SISTEMI ALAN ARAŞTIRMASI}

Araştırmanın daha iyi anlaşılabilmesi için bu kapsamda daha önce yapılmış benzer çalışmalar ile kıyaslanması ve diğer çalışmalar hakkında kısaca bilgi verilmesi yararlı olacaktır. Bu kapsamda sırasıyla literatür araştırması, araştırmanın metedolojisi ve bulguları ortaya konulacaktır. 


\subsection{Literatür Araştırması}

Araştırmada Türkiye'deki bir kooperatif müessesesinin faizsiz kredi sistemi faaliyetlerine elverişli olup olmadığı düzenlemeler ve kooperatif bankacılı̆̆ 1 ile katılım bankacılı̆̆ literatürde yapılmış olan çalışmalarda sadece bu ölçek düzeyinde incelenmiştir.

Selvanathan vd. (2018) tarafından yapılan araştırmada Malezya'nın Selangor eyaletinde İslami bankacılık ürün ve ve hizmetlerini seçiminde etkili faktörlerin belirlenmesi amacıyla basit tesadüfü örnekleme yöntemiyle veri toplanmıştır. Çalışmada İslami banka seçimi üzerinde banka itibariyle maliyet avantajı arasında pozitif ilişki olduğu belirlenmiştir. Ayrıca din faktörünün İslami bankacılık seçimi ile negatif ilişkili olduğu çalışmada tespit edilmiştir.

Al-Muharrami ve Hardy (2013) yapmış oldukları çalışmalarında, kooperatif bankalarının örnekleri olarak İslami bankalar ve kredi birlikleri olmak üzere iki tür finansal kurumu incelemişlerdir. Uygulamada önemli farkl1lıklar bulunmakla birlikte kooperatif bankasının ve özellikle kredi birliği ilkelerine göre ortakları ve yöneticileri bulunan bir kurumun İslami ilkelere göre çalışabileceğini ve bunun avantajları olabileceğini; kapsayıcılık ve risk paylaşımı ile ilgili İslami kurallara uymanın, tasarruf sahiplerinin çıkarlarının tamamen dikkate alınmasını sağlamak için teşvikleri güçlendireceğini göstermiştir. Aynı zamanda, bir kooperatif bankasının ortakları genelinde daha fazla risk paylaşımının ve bankanın maruz kaldığı risklere katılan tasarruf ürünlerinin, kurumu daha dirençli hale getireceğini ve ayrıca iyi yönetişim için teşvikleri güçlendirebileceğini belirtmektedir.

Jones (2008), yoksulluğu azaltma stratejilerine göre tasarruf ve kredi kooperatifleri felsefesinde bu kuruluşların yoksulluğu azaltma rolündeki temel kaymanın kredi yerine tasarruf üzerinde yapılan vurgu olduğunu belirtmektedir. Önceki dönemlerde tasarruf ve kredi kooperatifleri krediye erişim eksikliği ve riskli kredi sağlayıcılara güvenmenin yoksulları yoksullaşmadan koruyacağına inanılmasından dolayı yoksullara düşük maliyetli kredilerin sunulmasının, onları yoksulluktan kurtarmanın anahtarı olduğu kabul edilmiştir. Tasarruf ve kredi kooperatifleri, varlık ve tasarruf birikiminin öncelikli olması gerektiğini ve nihayetinde bunun insanları yoksulluktan kurtaracak bir araç olduğu daha iyi anlaşılmıştır.

Küçükkaplan (2003), çalışmasında kooperatif bankacılığı sistemi Alman ve İngiliz modelleri üzerinden incelenmiştir. Çalışmada kooperatif bankasının kurulması önerilmiştir. Türkiye'de kurulacak bir kooperatif bankasının kooperatiflerin finansman sıkıntısına çözüm olacağı kabul edilmektedir. Bankanın destekleri sağlamak için hangi kaynakları kullanması gerektiği ve kar payı dağıtımının nasıl yapılması gerektiği ile ilgili soruların yanıtlanması için diğer ülkelerdeki başarılı uygulamaların incelenmesi önerilmektedir.

Zarakolu (1954), makalesinde bankacılık ve kooperatifçilik bakımından küçük kredileri incelemiştir. Bankacıların küçük kredi davasına istekli görünmediklerini ve küçük mukrizlerin bankaların istediği teminata da sahip olmadıklarını belirtmektedir. Kendilerine bankaların kapalı olduğunu görenlerin murabahacılara müracaat zorunda kaldıklarını, bu sebeple, küçük kredi davasının eskiden beri devletleri, dini ve sosyal teşekkülleri ilgilendirdiğini, bir takım hayırseverlerin bu nevi kredileri teşkilâtlandırmak için gayret sarfına sevk ettiğini söylemektedir. Muhtelif memleketlerde müşahede edilen yardım sandıklarının, halk bankaları, esnaf kefalet kooperatifleri, zirai kredi kooperatifleri ile bu mühim ihtiyacın tezahür şekillerinden ibaret olduğunu belirtmektedir. Tefecilik ile mücadele edebilmek için de küçük müstakrizlere kredi kaynağı bulmak ve bir takım kredi müesseseleri meydana getirerek küçük müstakrizlerin istifadesine sunmanın gerektiğini de dile getirmektedir.

\subsection{Araştırmanın Yöntemi}

Tarım sektörünün önde gelen kurumlarından biri olan TKK kullandırdığı kredilerin yarısından fazlasını bankalardan finansman sağlayarak gerçekleştirir hâle gelmiştir. TKK, gerek bu gelişme gerekse de günümüz devlet politikası ile faizsiz kredi sistemini faaliyete koymayı gündeme almıştır. Çalışmanın amacı TKK' da bu sistemin uygulanabilirliğinin tespit etmek ve bir model önerisi sunmaktır. 


\subsubsection{Veri Toplama Araçları}

Araştırmada sosyal bilimlerde geniş kullanımı bulunan nitel araştırma yöntemine başvurulmuştur. Nitel araştırma kapsamında görüşme ve gözlem yöntemleri uygulanmıştır. Veri elde etme ile analiz işlemlerinin geçerliğinin sağlanması için toplanan verilerin aralarında tutarlı ve anlamlı olmasına özen gösterilmiştir.

Görüşme yöntemi ile alan yazın taraması ve uzman fikirleri çerçevesinde şekillendirilerek hazırlanan sorular belli bir sistematik dâhilinde katılımcılara sorularak cevap alınmıştır. Araştırmanın kapsamına bağı olarak görüşmelerde yüz yüze yöntemi kullanılmıștır ve sorular yap1 çerçevesinde sorulmuştur. Görüşmeler, Türkiye'de faaliyet gösteren 6 katılım bankası, katılım bankacılığında önde olan ülkelerden Malezya'da eski kooperatif bankası kimliğini muhafaza ederek İslami bankacılık faaliyeti gösteren Co-opbank Pertama ile TKK'da görev yapan konusunda uzman, eğitimli ve tecrübeli katılımcılarla yapılmıştır.

Araştırma verileri, faizsiz kredilendirme uygulaması bulunduran kurumların demografik özelliklerini ve faaliyetlerini öğrenmeye yönelik bilgileri içeren hazırlanan form aracılığ 1 ile toplanmıştır. Araştırmada TKK ile Co-opbank Pertama Malezya örneklem olarak kabul edilerek faaliyetleri analiz edilmiştir. Seçilen iki kurumun verilerinin karşılaştırılmasının yapılması amacıyla sistematik gözlem araştırması yapılmıştır.

\subsubsection{Araştırma Grubu}

Araştırma grubu, çalışma grubu amaçlı örnekleme usullerinden "maksimum çeşitlilik örnekleme" yöntemi kullanılarak seçilmiştir. Maksimum çeşitlilik örneklemesi diğer yöntemlerle varılacak bulgulara göre daha ayrıntılı sonuç sunabilmektedir. Ayrıca farklı durumlar arasında ortak olgular çıkarabilmektedir (Yıldırım ve Şimşek, 2016:119). Azami yelpazenin sağlanması doğrultusunda araştırma çerçevesinde görüşülecek idarecilerin kamu-özel-kooperatif gibi farklı türde faizsiz bankalarda görev yapıyor olmalarına dikkat edilmiştir. Araştırma çerçevesinde görüşülen idarecilerin hususiyetleri Tablo 3'de gösterilmektedir:

Tablo 3. Katılımcıların Özellikleri

\begin{tabular}{|c|c|c|c|c|c|c|}
\hline $\begin{array}{l}\text { Kat1lımc1 } \\
\text { Kodu }\end{array}$ & Cinsiyeti & Yaş1 & $\begin{array}{l}\text { Eğitim } \\
\text { Seviyesi }\end{array}$ & Çalıştığ 1 Kurum Çeşidi & $\begin{array}{l}\text { Görev } \\
\text { Süresi }\end{array}$ & $\begin{array}{c}\text { Görev Yapılan } \\
\text { Kurumun Şube Sayısı }\end{array}$ \\
\hline Katılımc1 1 & Erkek & 39 & Yüksek Lisans & Devlet Katılım Bankas1 & 11 & 97 \\
\hline Katılımc1 2 & Erkek & 34 & Yüksek Lisans & Devlet Katılım Bankası & 10 & 2 \\
\hline Katılımc1 3 & Erkek & 41 & Yüksek Lisans & Devlet Katılım Bankası & 13 & 88 \\
\hline Katılımc1 4 & Erkek & 37 & Yüksek Lisans & Özel Katılım Bankası & 13 & 310 \\
\hline Katılımc1 5 & Erkek & 39 & Lisans & Özel Katılım Bankası & 10 & 421 \\
\hline Katılımeı 6 & Erkek & 39 & Yüksek Lisans & Özel Katılım Bankası & 11 & 230 \\
\hline Katılımc1 7 & Erkek & 48 & Lisans & Kooperatif Bankası & 26 & 22 \\
\hline Katılımc1 8 & Erkek & 41 & Yüksek Lisans & Kooperatif & 14 & 1625 \\
\hline
\end{tabular}

Katılımcılar erkektir ve yaş ortalamaları yaklaşık 40 'tır. Tabloya göre araştırmaya katılan idarecilerin ikisinin lisans diğerlerinin yüksek lisans seviyesinde eğitim sahip oldukları görülmektedir. Görev süresi bakımından incelendiğinde araştırmaya katılan idarecilerin minimum 10 yıllık tecrübe sahibi oldukları anlaşılmaktadır. Türkiye'de faaliyette bulunan katılım bankalarının şube sayı toplamı 1143'tür. 


\subsubsection{Araştırmanın Bulguları}

Araştırma kurumların bilgi paylaşma iştah seviyesi ile sınırlıdır. Yapılan görüşmeler, veri doyumuna ulaşıldığına karar verildiğinden, araştırma açısından yeterli olarak değerlendirilmiştir. Elde edilen görüşme, gözlem ve doküman verileri içerik analizi yaklaşımıyla yorumlanmıştır. İçerik analizinde veriler temalar şeklinde düzenlendikten sonra derinlemesine analiz edilmektedir. (Yıldırım ve Şimşek, 2016:242). Araştırma boyunca sağlanan veriler sorulan sorulara göre aşağıdaki gibidir.

Tablo 4. Kurumların Müşteri Segmentleri

\begin{tabular}{|c|c|c|c|c|}
\hline & Bireysel & Kurumsal & Perakende & Kooperatif \\
\hline Kat1lımc1 1 & $\sqrt{ }$ & $\sqrt{ }$ & & \\
\hline Kat1lımc1 2 & $\sqrt{ }$ & $\sqrt{ }$ & & \\
\hline Kat1lımc1 3 & $\sqrt{ }$ & $\sqrt{ }$ & $\sqrt{ }$ & \\
\hline Kat1lımc1 4 & $\sqrt{ }$ & & & \\
\hline Kat111mc1 5 & & $\sqrt{ }$ & & \\
\hline Kat1l1mc1 6 & $\sqrt{ }$ & $\sqrt{ }$ & & \\
\hline Kat111mc1 7 & $\sqrt{ }$ & $\sqrt{ }$ & $\sqrt{ }$ & $\sqrt{ }$ \\
\hline Kat1l1mc1 8 & $\sqrt{ }$ & $\sqrt{ }$ & & $\sqrt{ }$ \\
\hline f & 7 & 7 & 2 & 2 \\
\hline
\end{tabular}

Katılım bankalarından olan katılımcılar bireysel ve vergiye tabi tüm şahıs firmaları ile şirketlerle çalıştıklarını belirtmişlerdir. Katılımc1 3; "bireysel müşterilerin perakendeye dönüşmeye başladığını", katılımc1 6; "çiftçiler genellikle küçük çaplı üretici oldukları için faturalı çalışmadığını ve bu yüzden katılım bankaları ile çalışmadıklarını, tarım sektöründe genellikle girdi üreticisi firmalarla çalıştıklarını" belirtmiştir.

Müşterileri arasında hayvancılık ve ürün yetiştiriciliği alanlarında çalışan kooperatif ve çiftçiler de bulunan Coopbank Pertama, mevduat topladığı ve kredi kullandırdığı müşterilerini perakende ve kurumsal olarak sınıflandırdığı görülmektedir. Katılım bankaları müşterilerinin yüzde seksenlik bölümünün kurumsal müşterilerden olduğunu ve tarım sektörüne yönelik faaliyetlerinin bulunmadığını belirtmişlerdir.

TKK, tarım alanında faaliyet gösteren ortak üreticilerine hem peşin hem de kredili satış gerçekleştirirken ortak olmayan bireylere de peşin satış yoluyla işlemlerini gerçekleştirdiği ayrıca ihale kanunundan muaf olması nedeniyle bazı kamu kurum ve kuruluşlarına ürün tedarik ettiği görülmüştür.

Tablo 5. Kurumların Yatırım ve Tasarruf Kaynakları

\begin{tabular}{|c|c|c|c|c|c|c|}
\hline & $\begin{array}{c}\text { Cari } \\
\text { Hesap }\end{array}$ & $\begin{array}{c}\text { Kat1lma } \\
\text { Hesab1 }\end{array}$ & $\begin{array}{c}\text { Kira } \\
\text { Sertifikas1 }\end{array}$ & $\begin{array}{c}\text { Ortaklık } \\
\text { Pay1 }\end{array}$ & Bankalar & $\begin{array}{c}\text { Gelir Gider } \\
\text { Fark1 }\end{array}$ \\
\hline Kat1lımc1 1 & $\sqrt{ }$ & $\sqrt{ }$ & & & & \\
\hline Kat1lımc1 2 & $\sqrt{ }$ & $\sqrt{ }$ & $\sqrt{ }$ & & & \\
\hline Kat1lımc1 3 & $\sqrt{ }$ & $\sqrt{ }$ & $\sqrt{ }$ & & & \\
\hline Kat1l1mc1 4 & $\sqrt{ }$ & $\sqrt{ }$ & $\sqrt{ }$ & & & \\
\hline Kat1lımc1 5 & $\sqrt{ }$ & $\sqrt{ }$ & $\sqrt{ }$ & & & \\
\hline Kat1lımc1 6 & $\sqrt{ }$ & $\sqrt{ }$ & $\sqrt{ }$ & & & \\
\hline Kat1lımc1 7 & & $\sqrt{ }$ & $\sqrt{ }$ & $\sqrt{ }$ & & \\
\hline Kat1lımc1 8 & & & & $\sqrt{ }$ & $\sqrt{ }$ & $\sqrt{ }$ \\
\hline f & 6 & 7 & 6 & 2 & 1 & 1 \\
\hline
\end{tabular}


Yukarıdaki tabloda incelenen kurumların fon toplama yöntemleri verilmiştir. Teoride faizsiz kredi sisteminin belirli müşterilerinin havuzdaki paraları ile fatura vb. ödemelerinin gerçekleştirildiği cari hesap ile fonların toplandığı ve bu fonlardan kredi verilen kâr zarara iştirak etme hesabı şeklinde iki fon temin usulü bulunmaktadır. Katılım bankaları katılımcıları kira sertifikalarını da fon temin etmek için kullandıklarını belirttiklerinden kira sertifikaları sukuk başlığı altında dâhil edilmiştir. Katılımcı 2;
"Katılım bankalarının kâr payı oranlarının faiz oranı ile aynı olmak zorunda olduğunu aksi takdirde düşük kâr payı uygulamasında müşterilerinin mevduat bankalarına fon yatıracağını ve yüksek kâr payı oranı vermeleri hâlinde kredi kullanmak isteyen müsterilerinin mevduat bankalarına yöneleceğini ve kâr payı oranlarını mevduat banka faiz oranlarını göz önünde bulundurularak belirlediklerini”,

ifade etmiştir. Katılıme 6 da benzer şekilde fon kullanan ve sunanlar arasında dengeyi korumaya çalıştıklarını belirtmiştir. Co-opbank Pertama'nın düşük kâr oranı verilen Al-Wadiah tasarruf hesabı katılma hesabı ve yüksek kâr oranı verdiği İslami yatırım uygulaması murabahayı senetlerle gerçekleştirdiği için bu uygulaması da sukuk çerçevesinde değerlendirilmiştir.

Kanuni yedek akçe, fevkalade yedek akçe, destekleme fonu, yatırım geliştirme fonu, tasfiye fonu ve risturnlardan oluşan müspet ve menfi gelir gider farklarını sermayesine dâhil ettiği için ve kullandırdığ 1 kredilerin sermayesinin karşılamadığı kısmını bankalardan sağladığı için bu kalemler TKK için fon kaynağı olarak ele alınmıştır. Mevduat toplama yetkisi olan TKK'nın ortaklarından tasarruf toplayarak finansman sorununa çözüm bulabileceği düşünülmektedir.

Tablo 6. Müşterilerin Kurumları Tercih Sebepleri

\begin{tabular}{|c|c|c|c|c|c|c|c|c|}
\hline & $\begin{array}{c}\text { Rahat } \\
\text { Erişebilirlik }\end{array}$ & $\begin{array}{c}\text { Güvenilir } \\
\text { Olması ve } \\
\text { İşlem Kalitesi }\end{array}$ & $\begin{array}{c}\text { Çevre } \\
\text { Tavsiyesi }\end{array}$ & $\begin{array}{l}\text { Çekici Kredi } \\
\text { ile Ödeme } \\
\text { Olanakları }\end{array}$ & $\begin{array}{l}\text { Ürün ile } \\
\text { Hizmet } \\
\text { Yelpazesi }\end{array}$ & $\begin{array}{c}\text { Rekabetçi } \\
\text { Kâr } \\
\text { Oranı }\end{array}$ & İletişim & Dini \\
\hline Katılımcı 1 & & $\sqrt{ }$ & & & $\sqrt{ }$ & $\sqrt{ }$ & $\sqrt{ }$ & \\
\hline Katılımcı 2 & & $\sqrt{ }$ & & & & & & \\
\hline Kat1lımc1 3 & & & & & & & $\sqrt{ }$ & $\sqrt{ }$ \\
\hline Katılımc1 4 & & & & $\sqrt{ }$ & $\sqrt{ }$ & & & $\sqrt{ }$ \\
\hline Kat1lıme1 5 & & $\sqrt{ }$ & & & & & & \\
\hline Kat1lımc1 6 & & & & & & & $\sqrt{ }$ & $\sqrt{ }$ \\
\hline Kat1lımc1 7 & & & & $\sqrt{ }$ & & $\sqrt{ }$ & & \\
\hline Katılımc1 8 & $\sqrt{ }$ & $\sqrt{ }$ & $\sqrt{ }$ & $\sqrt{ }$ & $\sqrt{ }$ & & & \\
\hline $\mathrm{f}$ & 1 & 4 & 1 & 3 & 3 & 2 & 3 & 3 \\
\hline
\end{tabular}

Katılımcıların müşterilerinin kurumları ile çalışma sebeplerine dair verdikleri cevaplar Tablo 6.'da gösterildiği gibidir. Yaptığımız incelemeye göre katılım bankalarının müşterilerini esas olarak yaptıkları ziyaretler ile sağladıkları görülmüştür. Bunun dışında İslami yönden hassas olan kişilerin bu kurumlarla çalışmasını ikinci önemli sebep olarak belirtebiliriz.

TKK'nın sahip olduğu şube ağı ve bu şekilde sağladığı rahat erişebilirlik faktörü ortaklarının en büyük tercih sebebi olduğunu görülmektedir. Yine ortaklarının TKK'ya güvendiği görülmüştür. Ancak TKK'nın müşteri portföyünün aynı zamanda mevduat bankalarıyla da çalıştığı gözlemlenmiştir. 
Tablo 7. Kurumların Sundukları Kanallar

\begin{tabular}{|c|c|c|c|c|c|c|c|c|c|}
\hline & $\begin{array}{c}\text { Kat1lıme1 } \\
1 \\
\end{array}$ & $\begin{array}{c}\text { Katılımc1 } \\
2 \\
\end{array}$ & $\begin{array}{c}\text { Katılımc1 } \\
3 \\
\end{array}$ & $\begin{array}{c}\text { Kat1lıme1 } \\
4 \\
\end{array}$ & $\begin{array}{c}\text { Katılıme1 } \\
5 \\
\end{array}$ & $\begin{array}{c}\text { Katılımeı } \\
6 \\
\end{array}$ & $\begin{array}{c}\text { Kat1lıme1 } \\
7 \\
\end{array}$ & $\begin{array}{c}\text { Kat1lımc1 } \\
8 \\
\end{array}$ & $\mathrm{f}$ \\
\hline Çağrı Merkezi & $\sqrt{ }$ & $\sqrt{ }$ & & & & $\sqrt{ }$ & $\sqrt{ }$ & $\sqrt{ }$ & 5 \\
\hline EFT & $\sqrt{ }$ & & & & & & & & 1 \\
\hline Havale & $\sqrt{ }$ & & & & & & & & 1 \\
\hline Otomatik Ödeme & $\sqrt{ }$ & & & & & & & & 1 \\
\hline Maaş & $\sqrt{ }$ & & & & & & & & 1 \\
\hline Kredi Kartı & $\sqrt{ }$ & & & $\sqrt{ }$ & $\sqrt{ }$ & & & & 3 \\
\hline Sigorta & & $\sqrt{ }$ & $\sqrt{ }$ & $\sqrt{ }$ & $\sqrt{ }$ & $\sqrt{ }$ & $\sqrt{ }$ & $\sqrt{ }$ & 7 \\
\hline ATM & & $\sqrt{ }$ & & $\sqrt{ }$ & & $\sqrt{ }$ & $\sqrt{ }$ & & 4 \\
\hline Mobil Bankacılık & & $\sqrt{ }$ & & & & $\sqrt{ }$ & $\sqrt{ }$ & & 3 \\
\hline İnternet Hizmetleri & & $\sqrt{ }$ & & & & $\sqrt{ }$ & $\sqrt{ }$ & & 3 \\
\hline Şube Operasyonları & & $\sqrt{ }$ & & & & $\sqrt{ }$ & $\sqrt{ }$ & & 3 \\
\hline TFX & & & & $\sqrt{ }$ & & & & & 1 \\
\hline Burs & & & & & & $\sqrt{ }$ & $\sqrt{ }$ & $\sqrt{ }$ & 3 \\
\hline Girdi & & & & & & & & $\sqrt{ }$ & 1 \\
\hline Eğitim & & & & & & & & $\sqrt{ }$ & 1 \\
\hline Desteklemeler & & & & & & & & $\sqrt{ }$ & 1 \\
\hline
\end{tabular}

Co-opbank Pertama'nın hem burs hem de Zekât-Esnaf Fisebilillah adı altında zekât uygulaması bulunmaktadır. Zekât uygulamasını ilk ve orta öğretim öğrencilerine uygulandıkları için burs başlığı ile birlikte değerlendirilmiştir. Katılımc1 4, "Kuyum, alkol, şans oyunları gibi ödemelere kapalı bulunan ve üreticilerin müstahsil ödemelerinde kullandığı tohum kart uygulamalarının bulunduğunu, kartın enflasyona endeksli olduğunu ve kâr oranı ile çalıştı̆̆ını" belirtmiştir.

Katılımc1 5, "Katılım bankacılığında ATM ve fiziki altın uygulamalarının sistem açısından uygun olmadiğını" ifade etmesine rağmen katılım bankalarının genelde diğer bankalar ile ortak ATM uygulaması bulunduğu görülmüştür. Katılım bankalarının sigorta hizmetini destek alarak gerçekleştirdiği içlerinden sadece katılımc1 5 'in mensubu olduğu katılım bankasının kendi tekafül sigorta şirketini kurduğu gözlemlenmiştir. Katılımcı 6, da; "Katılım bankalarının maaş promosyonu gibi bonus uygulamasının bulunmadığını", ifade etmiştir.

TKK'nın ortak ürün değerlendirme uygulaması girdi temini başlı̆̆ı altında değerlendirilmiştir. Bir katılım bankası hariç diğerlerinin TKK'nın iştiraki olan Bereket Sigorta'dan destek aldığı, sermayesi çiftçi ortaklarından gelen Bereket Sigorta'nın faaliyetlerinin katılımcı 8'in görüşme esnasında belirtiği gibi tekafül sigortacılığına benzediği, TKK'nın sigorta havuzuna topladığı fonları faiz hariç yatırım kanallarında kullanması ve ortaklarına Co-opbank Pertama gibi sigorta havuzundan faydalananlara kâr payı dağıtması hâline Bereket Sigorta'nın tekafül sigortası şeklinde yapılanmış olacağı gözlemlenmiştir. TKK'nın kredi kartı uygulamasının ise pilot uygulama aşamasında olduğu gözlemlenmiştir. 
Tablo 8. Kurumların Ana Faaliyetleri

\begin{tabular}{|c|c|c|c|c|c|c|c|c|c|}
\hline & Murabaha & $\begin{array}{c}\text { Karz-1 } \\
\text { Hasen }\end{array}$ & İcara & Selem & $\begin{array}{c}\text { Satıs ve Geri } \\
\text { Kiralama }\end{array}$ & İstisna & Risturn & $\begin{array}{c}\text { Peşin } \\
\text { Satış }\end{array}$ & $\begin{array}{c}\text { Ortak } \\
\text { Kredi }\end{array}$ \\
\hline Kat1lımc1 1 & $\sqrt{ }$ & $\sqrt{ }$ & & & & & & & \\
\hline Kat1lımc1 2 & $\sqrt{ }$ & $\sqrt{ }$ & $\sqrt{ }$ & $\sqrt{ }$ & & & & & \\
\hline Kat1lımc1 3 & $\sqrt{ }$ & & & & $\sqrt{ }$ & & & & \\
\hline Kat1lımc1 4 & $\sqrt{ }$ & & & & & & & & \\
\hline Kat1lımc1 5 & $\sqrt{ }$ & & $\sqrt{ }$ & $\sqrt{ }$ & & $\sqrt{ }$ & & & \\
\hline Kat1lımc1 6 & $\sqrt{ }$ & $\sqrt{ }$ & $\sqrt{ }$ & $\sqrt{ }$ & & $\sqrt{ }$ & & \\
\hline Kat1lımc1 7 & $\sqrt{ }$ & & & & & & $\sqrt{ }$ & & \\
\hline Kat1lımc1 8 & & & & & & & & $\sqrt{ }$ & $\sqrt{ }$ \\
\hline f & 7 & 3 & 3 & 3 & 1 & 2 & 1 & 1 & 1 \\
\hline
\end{tabular}

Faizsiz bankacılık sisteminde Mudarebe, Muşereke, Komodite ve Musakat gibi farklı fon kullandırma yöntemleri de bulunmakta birlikte katılımcılar esas itibariyle vekâleten gerçekleştirilen ticaret sonucunda alınan faturalar ile satıcıya bedel ödendiği Murabaha ile kredi verdiklerini, diğer yöntemlerin vekâletin yüze okunması ve istişare yapılması gibi uygulamalar ile murabaha şeklinde hayat bulduğunu belirtmişlerdir. Katılım bankaları katılımcılarından Karz-1 Hasen yönetimini uyguladıklarını belirtenler bu yol ile bazı müşterilerinin vergi vb. ödemelerinin bu şekilde yapıldığını ancak bir çeşit avans uygulaması olan bu yöntemin BDDK tarafından yerinde görülmemesi sadece yazınlarında bulunduğunu ifade etmişlerdir.

Kat1lımc1 2, "Büyük çaplı ithalat gibi durumlarda fatura gelmeden iki üç ay avans kredi uygulayabildiklerini" belirtmiştir ve bu uygulama faizsiz kredilendirme sistemi açısından fikhi boyutunda ilgililerce tartışma konusu olmuştur. Co-opbank Pertama'nın teverruk yani kâr beyanı ile emtia satımı ürünüyle murabaha fon kullanımı gerçekleştirdiği gözlemlenmiştir. TKK'nın faaliyetlerine baktığımız zaman ortak içi ve dışı peşin satış ile ortaklarına nakdi ve ayni kredi kullandırdığı görülmektedir. Ayrıca TKK ayni krediler ile yatırım kredilerini faizsiz olarak sunabilmektedir. TKK'nın kredi kullandırma yöntemi incelendiğinde ortaklarının girdi ihtiyaçlarını fatura karşıllğg hasat dönemine göre kredilendirdiği ve bunun murabaha benzediği görülmektedir. Yaptığımız görüşmelerde katılımc1 2;

“TKK'nın kredilerine vade fark üzerine operasyon ve personel giderlerini yansitarak faizsiz kredi sistemi uygulayabileceğini ama bu uygulamanın nasıl hayata geçirileceğinin soru işareti olduğunu ve çiftçilerin kabul edip etmeyeceğinin tartışmalı olduğunu, tarım kredinin misyonuna yoğunlaşması gerektiğini, özel sektörde verimsiz personel nasll iş akdi feshediliyorsa gerçek maliyetlerin ortaya çıkarılması için TKK'nın da bu şekilde davranması gerektiğini”,

kat1lımc1 3 ise;

"Katılım bankalarının vade farkı ile kredi kullandırdĭ̆ını, matematiksel yapılan hesabın faiz olarak adlandırılmasının yanlış olduğunu düşündüğ̈̈nü, TKK'nin bir şekilde mallara murabaha yöntemini uyguladı̆̆ını ve kredilere yansıttığ faizin aslında vade farkı olduğunu ve faiz ibaresinin adının değişstirilmesi hâlinde faizsiz bankacılık yaptı̆̆ı belirtilebileceğini",

katılımcı 6 da; "Katılım bankacılığında kredilerin TL bazlı kullandırıldı̆̆ını ve ödemelerin aylı olduğunu, TKK'nın kâr marjı koymadan vade sonunda birim fiyat üzerinden müstahsil ödemesi yapabileceğini" belirtmiştir. Yaptığımız incelemede belirtildiği gibi TKK'nın kredi sisteminin faizsiz kredi sistemine benzediği ancak kredilere personel ile operasyon giderlerinin yansitılması hâline bunun ortaklarda ciddi bir tepki ile karşılanacağı ve TKK açısından bu giderlerin hesaplanmasının oldukça güç olduğu gözlemlenmiştir. Ayrıca birçok durumda TKK, çektiği siparişlerin faturaları geç gelmesinden dolayı bu şekilde olan girdilerin kredilendirmesini girdi tesliminden sonra yapmaktadır. Katılım bankalarında da olan benzer kredilendirme sistemi bulunmakla beraber bu sıkıntıyı vekâlet yoluyla çözdükleri görülmektedir. Ancak TKK'da böyle bir durum olmadığı için TKK'nın bu uygulaması faizsiz kredilendirme sistemi açısından uygunluk teşkil etmemektedir. 
Tablo 9. Kurumların Gelir Kalemleri

\begin{tabular}{|c|c|c|c|c|c|}
\hline & Vade Fark1 & Hizmet Bedeli/Ücret & Kira & Kâr & Fonlar \\
\hline Kat1lımc1 1 & $\sqrt{ }$ & $\sqrt{ }$ & & & \\
\hline Katılımc1 2 & $\sqrt{ }$ & $\sqrt{ }$ & & & \\
\hline Katılımc1 3 & $\sqrt{ }$ & $\sqrt{ }$ & & & \\
\hline Katılımc1 4 & $\sqrt{ }$ & $\sqrt{ }$ & & & \\
\hline Katılımc1 5 & $\sqrt{ }$ & $\sqrt{ }$ & & & \\
\hline Katılımc1 6 & $\sqrt{ }$ & $\sqrt{ }$ & $\sqrt{ }$ & $\sqrt{ }$ & $\sqrt{ }$ \\
\hline Katılımc1 7 & $\sqrt{ }$ & 6 & 1 & 2 & 1 \\
\hline Katılımc1 8 & $\sqrt{ }$ & 8 & & & \\
\hline f & & & & & \\
\hline
\end{tabular}

Kurumların gelir unsurları yukarıdaki gibi belirtilmiştir. Tabloda, TKK'nın faiz geliri vade uygulaması ile benzer olduğu için bu kalem altında, Co-opbank Pertama'nın hizmet ücretine ilaveten ortaklarından aldığı üyelik ücreti hizmet bedeli altında ve iki kooperatif kurumunun satış kârı ile net kâr gelirleri kâr kalemi altında ele alınmıştır. TKK'nın kullandırdıkları kredilere faiz yanında yansıttığı fon kalemleri, diğer kurumlarla ayrıştığı gelir unsuru olarak görülmektedir.

Tablo 10. Kurumların Finansal Ürünleri

\begin{tabular}{|c|c|c|c|c|}
\hline & $\begin{array}{c}\text { Mal } \\
\text { Alımı }\end{array}$ & İhtiyaç & Nakdi & $\begin{array}{c}\text { Vade } \\
\text { Farksız }\end{array}$ \\
\hline Katılımc1 1 & $\sqrt{ }$ & $\sqrt{ }$ & & \\
\hline Kat1lımc1 2 & $\sqrt{ }$ & $\sqrt{ }$ & & \\
\hline Kat1lımc1 3 & $\sqrt{ }$ & $\sqrt{ }$ & & \\
\hline Kat1lımc1 4 & $\sqrt{ }$ & $\sqrt{ }$ & & \\
\hline Kat1lımc1 5 & $\sqrt{ }$ & $\sqrt{ }$ & & \\
\hline Kat1lımc1 6 & $\sqrt{ }$ & $\sqrt{ }$ & & \\
\hline Kat1lımc1 7 & $\sqrt{ }$ & $\sqrt{ }$ & & \\
\hline Kat1lımc1 8 & $\sqrt{ }$ & $\sqrt{ }$ & $\sqrt{ }$ & $\sqrt{ }$ \\
\hline f & 7 & 7 & 1 & 1 \\
\hline
\end{tabular}

Katılımcılar esas itibariyle inşaat demiri gibi mal alımına yönelik krediler ve konut, taşıt, sağlık, eğitim gibi kalemleri içeren ihtiyaç kredileri verdiklerini belirtmiştirler. Ayrıca nakdi kredi verilmesinin paranın nerede kullanılacağının belli olmaması nedeniyle sistemde yasak olduğunu belirtmişlerdir. Genel anlamda katılımcılar tekel, kumar, domuz ürünleri gibi kalemler içermeyen ve İslami açıdan caiz olan her türlü krediyi verdiklerini belirtmişlerdir. Katılımc1 6, “TKK'nın İmece Plastik iştirakinde olduğu gibi iştiraklerinde yar mamul ve mamul mal ürettiğini, bu yüzden İmece Plastik ile özellikle çalışmak istediklerini, katılım bankalarının esas itibariyle üretim kredisi vermek istediğini" söylemiştir. Arsa ve mülk mortgage kredileri ile bireysel kredi uygulamaları bulunan Co-opbank Pertama'nın da kredilerini murabaha ile gerçekleştirildiği görülmüştür.

Ortaklarına sağladığı girdi temini ile kredi uygulaması yaparak TKK'nın kredi sisteminin temelde faizsiz kredilendirme sistemi ile örtüştüğü görülmektedir. TKK ortaklarına 90 gün vadeye kadar vadeli faiz ürün satış1 yapmaktadır. Yenileme kredisi kapsamında kullandırılan nakdi krediler, nakdi kredilere dâhil edildiğinde kullandırılan nakdi kredilerin toplam kullandırılan kredilere oran1 2017 y1lına gelindiğinde Tablo 10'da da görüldüğg̈ üzere \%38'e dayandığı görülmektedir. Katılımc1 2, “Borç ödemesine yönelik kredilerin verilmediğini" ifade etmiştir. TKK' da borç yenilemesi uygulamasının oldukça yaygın olduğu gözlemlenmiştir. 
Tablo 11. Ortaklara Kullandırılan Krediler

\begin{tabular}{|c|c|c|c|c|}
\hline & $\mathbf{2 0 1 4}$ & $\mathbf{2 0 1 5}$ & $\mathbf{2 0 1 6}$ & $\mathbf{2 0 1 7}$ \\
\hline Yenileme Kredisi (†) & $624.426 .016,00$ & $396.522 .543,00$ & $656.149 .201,00$ & $670.595 .032,00$ \\
\hline Nakdi Krediler (†) & $1.557 .936 .984,00$ & $1.668 .146 .457,00$ & $1.866 .247 .799,00$ & $2.228 .753 .968,00$ \\
\hline Toplam (†) & $2.182 .363 .000,00$ & $2.064 .669 .000,00$ & $2.522 .397 .000,00$ & $2.899 .349 .000,00$ \\
\hline $\begin{array}{c}\text { Kullandirılan Kredi (†) } \\
\text { Nakdi-Yenileme Kredilerin } \\
\text { Oranı (\%) }\end{array}$ & $5.947 .587 .441,00$ & $6.405 .798 .867,00$ & $6.765 .228 .505,00$ & $7.619 .314 .092,00$ \\
\hline
\end{tabular}

Kaynak: Türkiye Tarım Kredi Kooperatifleri Merkez Birliği, 2018; Türkiye Tarım Kredi Kooperatifleri, 2018; verileri kullanılarak oluşturulmuştur.

Tablo 12. Faizsiz Kredilendirme Sisteminin Değerlendirilmesi

\begin{tabular}{|c|c|c|c|c|c|c|c|c|c|}
\hline & \multicolumn{5}{|c|}{ Artı Yönler } & \multicolumn{3}{|c|}{ Eksi Yönler } & \multirow[b]{2}{*}{ Tanitım } \\
\hline & $\begin{array}{c}\text { Kapitalizme } \\
\text { Karşı }\end{array}$ & $\begin{array}{l}\text { Gerçek } \\
\text { Ticaret }\end{array}$ & $\begin{array}{c}\text { Ürün } \\
\text { Çeşitliliği }\end{array}$ & Kaydilik & $\begin{array}{l}\text { Köklü } \\
\text { Sistem }\end{array}$ & Mevzuat & $\begin{array}{l}\text { Zarar } \\
\text { Riski }\end{array}$ & $\begin{array}{c}\text { Diş } \\
\text { Politika }\end{array}$ & \\
\hline Katılımc1 1 & $\sqrt{ }$ & & & & & & & & \\
\hline Katılımc1 2 & $\sqrt{ }$ & $\sqrt{ }$ & $\sqrt{ }$ & & & & $\sqrt{ }$ & & $\sqrt{ }$ \\
\hline Katılımeı 3 & & $\sqrt{ }$ & & & & $\sqrt{ }$ & $\sqrt{ }$ & & $\sqrt{ }$ \\
\hline Katılımc1 4 & $\sqrt{ }$ & $\sqrt{ }$ & $\sqrt{ }$ & & $\sqrt{ }$ & & & & \\
\hline Katılımc1 5 & $\sqrt{ }$ & & $\sqrt{ }$ & $\sqrt{ }$ & & $\sqrt{ }$ & & & $\sqrt{ }$ \\
\hline Katılımeı 6 & & $\sqrt{ }$ & $\sqrt{ }$ & & $\sqrt{ }$ & & $\sqrt{ }$ & $\sqrt{ }$ & \\
\hline Katılımc1 7 & $\sqrt{ }$ & & & & & & & & \\
\hline $\mathrm{f}$ & 5 & 4 & 4 & 1 & 2 & 2 & 3 & 1 & 3 \\
\hline
\end{tabular}

Katılımcılar finansal kiralama yönteminin mevduat bankalarına göre kendilerinin çok büyük artısı olduğunu belirtmişlerdir. Genel anlamda katılım bankalarının faizsizlik prensibini benimsemesi ile sosyal adalet açısından kapitalizmin katılığına karşı koyduğunu, vergi denetimini sağladığı için kaydi ekonomiyi teşvik ettiğini, İslam ülkeleri ile çalıştıkları için dış politikalar nedeniyle Mısır-Cezayir gibi ülkelere verdikleri kredilerin olumsuz etkilendiğini, kamu spotu yapmalarının yasak olduğunu, faizli sistem üzerine kurulu Merkez Bankasına bağlı çalıştıkları için mevzuat eksikliklerinin olduğunu ifade edilmiştir. Katılımcı 2;

“Katılım bankalarında çalışan personelin çoğunun kendi sistemlerini tam anlamıyla bilmediğini, kira sertifikası piyasasının her geçen gün büyüdüğ̈̈nü, faizsiz fonların gelişmesine paralel olarak sukukun öneminin daha da atı̆̆ını ve sektörün büyümesi ivme kazandığını, katılım bankalarının batmasının mümkün olmadığını, artık bankacılı̆̆ın BDDK ile TMFS tarafindan çok güçlü bir sistemde ayaklarını yere bastı̆̆ını, Bank Asya'nın özel durumundan dolayı devlet tarafindan kapatıldığı, katılım bankalarının kaydi para yaratmadığını",

kat1limc1 3;

“Enflasyon oranı yüksek olduğu dönemlerde katılım hesaplarının zarar ettiğini”, katılımcı 5 ise,

"Tamamen Íslami bankacılık yaptıklarını diyemeyeceklerini ancak sistemin özünde biraz daha doğru bir uygulama yapmaya çalıştığını, zarar eden kira sertifikalarının havuzdan çıkarıldı̆̆ için katılım bankalarının genel anlamda zarar etmeyeceğini, zarar olsa bile yatırımcı ortakların sermaye artırımına gittiğini”, 
belirtmişlerdir. $\mathrm{Bu}$ bağlamda katılım bankalarının borçlarını tahsil edememe riskinden başka zarar etme durumunun bulunmadığ 1 belirtebiliriz. Katılım bankalarından olan katılımcılar genel olarak bankacılık sektöründeki paylarının \%5 seviyesinde olduğunu ve bu oranı \%20'ye çıkarmak istediklerini, katılım bankacılığının daha da gelişeceğini ifade etmişlerdir. Nüfusunun büyük bir çoğunluğu Müslüman halktan oluşan Türkiye'de katılım bankalarının sektör payının düşük olması ve gelişme düzeyinin düşük olması dikkat çeken bir durumdur. Çeşitli araştırmalarda müş̧erilerin İslami finans algısının düşük olduğu, katılım bankalarının doğrudan finansman ihtiyacını karşılayamadığı ortaya konulmuştur (Terzi vd., 2019:177-179). Ayrıca katılımcı 1, "Avrupa'da faiz oranlarının sifir civarında bulunduğunu, mevduat bankalarının bir kisminın farkinda olmadan faizsiz bankacılık yaptığını" dile getirmiştir. Nitekim Birleşik Krallık’ta 5 İslami bankanın yanında BNP Paribas, Standart Chartered, Citi Bank, Barclays gibi bankaların da 15 İslami bankacılık enstrümanı bulunmaktadır. (British Embassy Bishkek, 2015:5). Kat1lımc1 2;

“Bankacılık faaliyeti yapılması durumunda TKK'nın doğabilecek zararlarının karşılanması noktasında devlet desteğinin alınabileceğini ancak bunun içinde kamuya bağgl bir kuruluş hâline gelinmesi gerektiği, TKK'nın yeni kanun düzenlemesi ihtiyacı duyacağını ve özellikle üst yöneticilerin bankacılık sektöründe donanımlı kişilerin olmasını gerektiğini"

ve katılımc 3; "PTT Bank ve Halkbankası'nın katılım bankacılığ hazırlıklarının devam ettiğini ancak faizsiz kredilendirme sisteminin sıfirdan kurulmasının ciddi anlamda güçlükler barındirdı̆̆ından sorun yaşayacaklarını, TKK'nın da sıkıntılar yaşayacağını", belirtmiştir. TKK, güneydoğu bölgesinde Vakıf Katılım Bankası ile \%50'şer ortaklık üzerinden tesis kurmuştur.

\section{SONUÇ}

İlk örneğini, 1864 de Almanya'da kurulan Raiffeisen kooperatifinden alan Tarım Kredi Kooperatifleri, bankaların yetişemediği yerlerde küçük ziraat işletmeleri tefecilerin istismarından kurtaran, ülkelerdeki banka teşkilâtını tamamlayan müesseselerdir.

Sert ortaklık koşulları, erteleme ve taksitlendirme işlemlerinden dolayı kredilerin donması, tahsil imkânı yitirilen kredilere yönelik tasfiye sisteminin olmaması gibi nedenlerden dolayı faaliyetlerini sürdürme konusunda tehlikeye düşme ihtimali ile karşı karşıya gelmemek için TKK'nın kredi faaliyetlerini, ortaklarının faaliyetlerinin devamlılığını sağlayacak bir şekilde yeniden organize etmesi gerektiği görülmektedir. TKK'nın yeterince etkili olamayışının temel nedeni finansman sorununu çözememiş olmasıdır.

Dünyada çoğunluğu tarım sektörünü finanse etmek üzere kurulmuş olan kooperatiflerin bankaları bulunmakta ve finansmanı genel olarak bu bankalar tarafından toplanan mevduatlar ile sağlanmaktadır (Küçükkaplan, 2002:61). Ancak Türkiye'de bir kooperatifler bankası faaliyet göstermemektedir. Bu doğrultuda TKK, kullandırdığ 1 kredilerin \%51'ini TCZB ve diğer bankalardan kredi çekerek finansman sağlamaya başlamıştır. Ancak bankalardan alınmakta olan kredilerin ölçek büyüklüğü ile kıyaslandığında yeterli olmadığı ve ortakların kredi ihtiyaçlarını karşılamaktan uzak kaldığı anlaşılmaktadır.

Geçmiş yıllarda TKK tarafindan tasfiye olan bir katılım bankası Bank Asya'yı iştirakler bünyesine katılması planlanmıştır. Ancak bu girişim, devlet kanalında destek bulmaması nedeniyle sonuçlanmamıştır. Mevcut durumunda bu hedefin gerçekleşmesi, devlet kanalında farkındalık oluşturulması ve ciddi altyapı çalışmaları yapılması gerektiği için kısa vadece zor gözükmemektedir.

Tüm bu gelişmelerin akabinde TKK faizsiz kredilendirme sistemini uygulama ve sukuk çıkarma konularını gündemine almıştır. Araştırmamız doğrultusunda yaptı̆̆ımız çalışmalarda faizsizlik prensibi ile çalışan Türkiye'deki katılım bankacılığı ve Co-opbank Pertama Malezya incelenmiştir. Bu doğrultuda faizsiz kredi sistemi ile ilgili şunları belirtebiliriz;

- Türkiye \%99 oranında Müslüman bir ülke olmasına rağmen faizsiz kredilendirme sisteminin payının \%5 gibi bir oran olduğu görülmektedir. Burada müşterilerin içerisinde dini hassasiyeti olmayanların da bulunduğu düşünüldügünde bu çok düşük bir orandır. Müşterilerin daha çok getiri elde etmek için mevduat bankalarına kayması veya bu bankalarla birlikte çalışması sistemin zayıf yönüdür. Ayrıca faizsiz kredilendirme sisteminde bireysel müşteri oranının çok düşük olduğu görülmektedir. Türkiye'de Doğu, Güneydoğu ve İç Anadolu bölgelerinde bulunan kooperatiflerin küçük çaplı olduğu gözlemlenmiştir. Akdeniz, Ege, Marmara bölgelerindeki kooperatifler ise büyük ölçeklidir. Bu bağlamda genel olarak ortakların faizden çok kredi imkânlarından ve yansıtılan fonların yükünden şikâyetçi oldukları ve ortakların büyük çoğunluğunun mevduat bankalarıyla da çalıştı̆̆ gözlemlenmiştir. 
UYSAL, Maşuk Cahit - Tarım Kredi Kooperatiflerinde Faizsiz Kredi Sisteminin Uygulanabilirliği: Bir Model Önerisi

- Sistemin cari hesap, katılma hesabı ve kira sertifikası olmak üzere üç fon toplama yöntemi bulunmaktadır. Türkiye'de de Hazine ve Maliye Bakanlığı 2012 yılından itibaren sukuk yani kira sertifikası ihraç etmektedir (Terzi vd., 2019:169). Yetersiz finansman ihtiyacını karşılama noktasında TKK'nın da yararlanabileceği bir uygulama olan sukuk, finansman sorununun çözümü açısından geçici bir yarar sağlayacaktır ve tamamen kendi öz kaynakları ile kredi sağlama noktasında yetersiz kalacaktır.

- Sistemde fon kullandırma yöntemleri olarak Murabaha, Mudarebe, Müşarke, İcara, Selem, Karz-1 Hasen, Komodite ve Musakat geçmekle beraber katılım bankaları tarafından uygulamada Murabahanın yer bulduğu ve Co-opbank Pertama'nın da bu yöntemle kredi kullandırdığı görülmüştür. Faizsiz kredi sistemi fatura karşılığ mal kredisi kullandırma esasına dayandığı ve bunu da vade farkı yansıtarak Murabaha yöntemiyle gerçekleştirdiği görülmüştür. Ortaklarının yem, gübre, motorin, zirai ilaç ve ekipman gibi ihtiyaçlarını karşılayan TKK, benzer şekilde fatura karşıllğı senet üzerinden kredi vermektedir. İki kredi sisteminin esasta aynı yöntem üzerine kurulu olduğu ve TKK'nın aldığı faizin aslında vade farkı olduğu düşünülmesi hâlinde TKK'nın faizsiz kredi sisteminde çalıştı̆̆ belirtilebilir. Ancak burada üç husus öne çıkmaktadır. İlk olarak uygulanan faizi vade farkı olarak adlandırılması hâlinde TKK'nın operasyon ve personel maliyetlerini de kullandırdığı kredilere yansıtması gerekmektedir. Bu ise teknik açıdan oldukça zor olduğu ve ortaklar tarafından kabul görmeyeceği anlaşılmıştır. İkinci olarak, katılımcıların belirttiği gibi sistemde krediler tutar üzerinden kullandırılmaktadır ve ödemeler aylık yapılmaktadır. TKK, ortakların aldığı malları vade sonunda karşılık gelen fiyatları üzerinden kredilendirmesi hâlinde ise bu uygulama ile TKK'nın maliyetlerini dahi karşılayamayacağı görülmektedir. Üçüncü husus ise faizsiz kredilendirme sisteminde nakdi kredi kullandırılmasının ve borç karşıllı̆̆ kredi verilmesinin yasak olmasıdır. Her ne kadar nakdi kredilerin TKK'da sınırlı kullandırıldığı görülse de borç yenilemelerin nakdi kredi ile yapıldığı ve bu şekilde nakdi kredi kullandırma oranının \%38'i bulduğu, ortaklar tarafından da ciddi oranda nakdi kredi talep edildiği görülmektedir. Ayrıca TKK'da, ortaklar alacakları ürünleri dönem dönem avans ödeyerek temin etmektedirler ve vadesinde tahsil edilmeyen vadeli faizsiz satışlara faiz yansıtılmaktadır. Bu uygulamalar da faizsiz kredilendirme sistemi ile örtüşmemektedir.

- Katılım hesaplarındaki kâr paylarının mevduat banka faiz oranlarına göre belirlendiği görülmektedir. Bu ise sisteme yönelik bir tartışma konusudur. Sistemin yurt dışında başarılı bir şekilde uygulanmasının ardında bu ülkelerdeki faiz oranlarının çok düşük, sıfır ve hatta eksi faiz olduğunu belirtebiliriz. $\mathrm{Bu}$ doğrultuda dilimize faiz ismiyle Kuran'dan çevirdiğimiz kelimenin riba olduğu ve bunun haksız artış denilebileceği, modern ekonomideki faiz ile karıştırıldığı ifade edilmektedir (Ahmad, 1978:183). Yavuz (1991), Bakkal (1995) ve Keleş (1998) yaptıkları çalışmalarda enflasyon oranı nispetindeki fazlalığının faiz olmadığını belirtmektedir (Destebaşı, 2018:33). İslam hukukunda da borçlanmalarda enflasyon farkının ödenmesi gerektiği belirtilmektedir (Habergetiren, 2017:29). Türkiye'de hâlihazırdaki faiz oranı reel enflasyon oranından düşüktür. Bu doğrultuda TKK'nın faize ilave olarak kredilere yansıttığı unsurları kaldırması hâlinde mal fiyatı üzerine uyguladığ 1 oranların vade fark1 olarak ele alınabileceğini belirtebiliriz. Katılımcılar içerisinde benzer yönde görüşler sunanlar olduğu görülmektedir.

$\mathrm{Bu}$ değerlendirmeleri göz önüne aldığımızda TKK'nın faizsiz kredilendirme sisteminde faaliyet göstermesinin faaliyet şekliyle örtüşmediği, ortaklarının ihtiyaçlarını karşılama noktasında da yetersiz kalacağı, ciddi bir uzmanlık gerektiren bir alan olması açısından hayata geçirilmesinin mümkün olmadığı anlaşılmaktadır. Kooperatifler ortaklarının ihtiyaçlarını gidermek ve çıkarlarını korumak için kurulan kuruluşlardır. Bu doğrultuda kooperatif yöneticileri kurumsal hedefleri planlarken ortaklarının görüşleri yönünde hareket etmelilerdir. TKK'nın 2017 yılı rakamları doğrultusunda, bankalardan kullandırılan kredinin öz kaynaklara çevrilebilmesi için kayıtlı ortak başı 4.287,91 € ve faal ortak başı 7.343,89 € ilave ortaklık payının yeterli olacağ 1 görünmektedir.

Yaptığımız gözlemlerde ortakların risturn dağıtılması ve mevduat bankalarından düşük faizli kredi verilmesi hâlinde TKK'nın ortaklarının bu ilave pay artırımlarını sağlayacağı görülmüştür. Bu doğrultuda TKK'nın, eskiden bir tasarruf kredi kooperatifi olan, kooperatif ortaklarına ortak olmayan müşterilerine nazaran daha cazip kredi sunan ve hâlihazırda banka şeklinde faaliyetlerini yürüten Co-opbank Pertama gibi yeniden yapılanmasının uygun olacağı görülmektedir.

Strateji analizlerinde kullanılabilecek genel kriterler; alakalılık, maliyetler, teknik uygulanabilirlik, değişik paydaşların fikirleri, hâlihazırdaki kaynaklar, siyasi uygunluk, verimsellik ile etkinlik, toplumsal kabul görme, diğer projeleri tamamlayıcılık ile aciliyettir. Farklı düzeylerdeki stratejiler birbirinden bağımsız olarak değerlendirildiğinde TKK açısından, en uygun yapılanmanın tasarruf kredi kooperatifi örgütlenmesi olduğu görülmektedir. 
1581 sayılı kanunun 3 üncü maddesi ile TKK'ya mevduat toplama ve bankacılık hizmetleri yapma yetkisi verilmiş, ayrıca merkez birliği, "Kooperatifler ile bölge birliklerinin toplayacakları mevduatların kullanılım usul ve esaslartyla bu husustaki üst kuruluşlar ile ilişkileri gösteren yönetmelik oluşturularak Ticaret Bakanlığına iletmek" ile görevlendirilmiştir. Yine kanunun 16, 17 ve 18 inci maddelerinde;

“Bireylerin bu kurumlardaki tasarruf mevduatlarından 3000 Е'ye kadarkı kısım, faiz dışında haciz olunamayacağl, tasarruf mevduatı sahipleri mevduatlarının \%50'si için kooperatif ile bölge birliklerinde bulunan klymetlerde imtiyazl alacakl olduklarl, mevduat cetvellerinin ve hesap özetlerinin verileceği, Türkiye Cumhuriyet Merkez Bankasina yatırlacak munzam mevduat karşılıklarının TCZB tarımsal finansmanlarına yönlendirilecek bölümün \%50'si benzer gaye ile usullerle merkez birliği yetkisine verileceğgi",

belirtilmiştir. Tarım Kredi Kooperatifleri anasözlesmesinin 17 inci maddesinde de, "Ortakların ödenen sermayelerine, merkez birliği yönetim kurulu tarafindan belirlenecek usullere göre faiz verilebilir", ifadesi yer almaktadır (Türkiye Tarım Kredi Kooperatifleri Merkez Birliği Genel Müdürlüğü, 2006:32). TKK’nın gerekli desteği alarak mevduat toplama yetkisini aktive etmesi politik açıdan yapılabilir durumdadır.

Tasarruf kredi kooperatifi örgütlenmesi ile TKK, ortakların ayni ihtiyaçlarını kooperatif bünyesinde veya ayrı noktalarda sadece peşin satış yaparak karşılayabilir, peşin alma gücü bulunmayan ortaklarına limitleri dâhilinde nakdi kredi verebilir.

Sonuç olarak; tasarruf kredi kooperatifçilik yöntemi ilerleyen dönemlerde TKK'nın kooperatif bankasına dönüşmesi yolunda büyük bir mihenk taşı da olacaktır. Bu öneriler doğrultusunda TKK ve dolayısı ile Türk kooperatifçiliğinin dünya kooperatif̧̧iliği içindeki yerini alması gerçekleştirilmiş olacaktır. Aksi hâlde, 2017 y1lı sonu itibariyle 84,5 milyar € olan Türkiye tarımsal kredi pazarında toplam 7,5 milyar € ikrazat rakamı ile TKK'nın uzun vadede istediği ilerlemeyi yakalamada zorluklarla karşılaşabileceği değerlendirilmektedir.

\section{KAYNAKÇA}

AHMAD, Ziauddin (1978), "The Theory of Riba", İslamic Studies, S.17(4), ss.171-185.

AKIN, Cihangir (1986), Faizsiz Bankacılık ve Kalkınma, Kayıhan Kitabevi, İstanbul.

AL-MUHARRAMI, Saeed ve HARDY, Daniel C. (2013), Cooperative and Islamic Banks: What can they Learn from Each Other?, IMF Working Paper Monetary and Capital Markets, International Monetary Fund.

BIRCHALL, Johnston ve KETILSON, Lou Hammond (2009), Resilience of the Cooperative Business Model in Times of Crisis, International Labour Organization, Cenova.

BRITISH EMBASSY BISHKEK (2015), Islamic Finance in the UK, Londra.

ÇIKIN, Ayhan (1996), Türkiye'de Bir Kooperatifler Bankası Kurulması İhtiyacı Nedenleri ve Hedefleri, Friedric Ebert Vakfi Yayını, İstanbul.

DESTEBAŞI, Ayşe Nur (2018), "Enflasyon ve Faiz İlişkisi Üzerine İslamiyet Açısından Bir Değerlendirme", Enderun Dergisi, S.2(1), ss.32-38.

De VRIES, Bouke (2009), "European Co-operative Banks in Financial and Economic Turmoil", The Expert Group Meeting On Cooperatives, New York, United Nations, ss.3-4.

DEVELTERE, Patrick, POLLET, Ignace ve WANAYAMA, Frederick (2008), Cooperating out of Poverty; The Renaissance of the African Cooperative Movement, ILO Publisher, Geneva.

DOĞAN, Sibel (2008), "Katılım Bankaları ve Ekonomiye Etkileri: Türkiye Örneği", Yayımlanmamış Yüksek Lisans Tezi, Sütçüimam Üniveristesi Sosyal Bilimler Enstitüsü, Kahramanmaraş.

HABERGETİREN, Ömer Faruk (2017), "İslam Hukukunda Paranın Değer Kaybının Ödenmesini Gerektiren Esaslar", Türkiye İlahiyat Araştırmaları Dergisi, S.1(1), ss.19-31.

ISDB (2020), "What We Do", İslamic Development Bank, Cidde, https://www.isdb.org/what-we-do (Erişim Tarihi: 02.09.2020).

İNAN, İsmail Hakk1 (2008), Türkiye'de Tarımsal Kooperatifçilik ve AB Modeli, İstanbul Ticaret Odas1 Yayını, İstanbul, 2. Baskı. 
JONES, Paul A. (2008), "From Tackling Poverty to Achieving Financial Inclusion - The Changing Role of British Credit Unions in Low Income Communities", The Journal of Socio - Economics, S.37(6), ss.2141-2154.

KOÇ, Hakan (2001), Kooperatifçilik Bilgileri, Nobel Yayın Dağıtım, Ankara.

KÜÇÜKKAPLAN, İlhan (2002), "Kooperatif Bankacılı̆̆ Dünyadaki Uygulaması ve Türkiye'de Uygulanabilirliği", Yayımlanmamış Yüksek Lisans Tezi, Gazi Üniversitesi Eğitim Bilimleri Enstitüsü, Ankara.

KÜÇÜKKAPLAN, İlhan (2003), "Kooperatif Bankacıll̆ğ ve Dünya Genelindeki Uygulamaları”, Süleyman Demirel Üniversitesi İktisadi ve İdari Bilimler Fakültesi, S.8(3), ss.27-48.

ÖZGÜR, Özgür (2007), "Katılım Bankalarının Finansal Etkinliği ve Mevduat Bankalart ile Rekabet Edebilirliği", Yayımlanmamış Doktora Tezi, Afyon Kocatepe Üniversitesi Sosyal Bilimler Enstitüsü, Afyonkarahisar.

ÖZSOY, İsmail (2013), "Katılım Bankacılığı Nedir, Ne Değildir?", Yeni Ümit Dini İlimler ve Kültür Dergisi, S.25(100), ss.10-11.

ÖZULUCAN, Abitter ve DERAN, Ali (2009), "Katılım Bankacılı̆̆ İle Geleneksel Bankaların Bankacılık Hizmetleri ve Muhasebe Uygulamaları Açısından Karşılaştırılması", Mustafa Kemal Üniversitesi Sosyal Bilimler Enstitüsü Dergisi, S.6(11), ss.85-108.

SELVANATHAN, Mahiswaran, NADARAJAN, Dineswary, ZAMRI, Amelia, SUPPRAMANIAM, Subaashnii ve MUMHAMMAD, Ahmad (2018), "An Exploratory Study on Customers' Selection in Choosing Islamic Banking", International Business Research, S.11(5), ss.42-49.

TERZİ, Hasan, APAN, Mehmet, ATAR Abüdlkadir ve ŞAHİN, Halil (2019), "Bireysel Müşterilerin Katılım Bankalarını Tercih Etme Tutumları Etkileyen Faktörlerin Belirlenmesi Üzerine Kültürlerarası Karşılaştırma: Türkiye ve Avrupa Örneği", Katılım Finansmanında Yeni Yaklaşımlar II, TKBB Yayınları, İstanbul, ss.165-200.

TUNÇ, Hüseyin (2010), Katılım Bankacılğı Felsefesi, Teorisi ve Türkiye Uygulaması, Nesil Yayınları, İstanbul.

TURAN, Güngör ve GÖKALP, Mehmet Faysal (1993), İslam Toplumlarının Ekonomik Yapısı, Fey Vakfı Yayını, İstanbul.

TÜRKIYE TARIM KREDİ KOOPERATIFLERİ (2018), 2017 Yılsonu Faaliyet Raporu, Muhasebe ve Finansman Daire Başkanlığı Bütçe ve Raporlama Müdürlüğü Yayını, Ankara.

TÜRKIYE TARIM KREDİ KOOPERATIIFLERİ MERKEZ BİRLIĞİ (2018), 2017 İstatistik Yıllığı, Strateji Geliştirme ve Teşkilatlandırma Daire Başkanlığı Yayını, Ankara.

TÜRKIYE TARIM KREDİ KOOPERATIFLERİ MERKEZ BİRLİĞİ GENEL MÜDÜRLÜĞÜ (2006), 1581 Sayılı Tarım Kredi Kooperatifleri ve Birlikleri Kanunu İle Anasözleşmeler, APK Daire Başkanlığı Yayını, Ankara.

TÜRKIYY TARIM KREDİ KOOPERATİFLERİ MERKEZ BİRLİĞİ GENEL MÜDÜRLÜĞÜ (2007), 30. Yl, Türkiye Tarım Kredi Kooperatifleri Merkez Birliği Genel Müdürlüğü Yayını, Ankara.

UÇAR, Mustafa (1992), Türkiye'de-Dünya'da Faizsiz Bankacılık ve Hesap Sistemleri, Fey Vakfı Yayını, İstanbul.

UYSAL, Maşuk Cahit (2019), "Türkiye Tarım Kredi Kooperatifleri ve Faizsiz Kredi Sisteminin Uygulanabilirliği", VI. Yıldız Uluslararası Sosyal Bilimler Kongresi Özet Bildiriler Kitabı, 12-13 Aralık 2019 - İstanbul, Yıldı Teknik Üniversitesi Yayın1, İstanbul, ss.509, http://www.sbe.yildiz.edu.tr/media/files/6_YSBK-OzetBildiriKitabiv7.pdf (Erişim Tarihi: 03.05.2020).

WORLD BANK (2008), Finance for All? Policies and Pitfalls in Expanding Access, World Bank Publisher, Washington D.C.. 
YILDIRIM, Ali ve ŞİMŞEK, Hasan (2016), Sosyal Bilimlerde Nitel Araştırma Yöntemleri, Seçkin Yayıncilık, Ankara.

ZAİM, Sabahattin (2005), Türkiye'nin Yirminci Yüzyılı: Toplum, İktisat, Siyaset, İşaret Yayınları, İstanbul.

ZARAKOLU, Avni (1954), "Memleketimizde Bankacılık ve Kooperatifçilik Bakımından Küçük Kredi”, Ankara Üniversitesi Hukuk Fakültesi Dergisi, S.11(3-4), ss.347-368.

1163 sayılı Kooperatifler Kanunu (10.05.1969 tarih ve 13195 sayılı Resmi Gazete).

1581 sayılı Tarım Kredi Kooperatifleri ve Birlikleri Kanunu (28.04.1972 tarih ve 14172 sayılı Resmi Gazete).

Özel Finans Kurumlarının Kurulmasına Yönelik Karar (19.12.1983 tarih ve 18256 Mükerrer sayılı Resmi Gazete). 